University of Nebraska - Lincoln

DigitalCommons@University of Nebraska - Lincoln

Faculty Publications from the Harold W. Manter Laboratory of Parasitology

Parasitology, Harold W. Manter Laboratory of

2009

\title{
Evaluation of Some Vulval Appendages in Nematode Taxonomy
}

Lynn K. Carta

United States Department of Agriculture-Agricultural Research Service, lynn.carta@ars.usda

Zafar A. Handoo

United States Department of Agriculture-Agricultural Research Service, handooz@ars.usda.gov

Eric P. Hoberg

United States National Parasite Collection, ehoberg@ggpl.arsusda.gov

Eric F. Erbe

United States Department of Agriculture, weekserbe@verizon.net

William P. Wergin

United States Department of Agriculture, wwergin@msn.com

Follow this and additional works at: https://digitalcommons.unl.edu/parasitologyfacpubs

Part of the Parasitology Commons

Carta, Lynn K.; Handoo, Zafar A.; Hoberg, Eric P.; Erbe, Eric F.; and Wergin, William P., "Evaluation of Some Vulval Appendages in Nematode Taxonomy" (2009). Faculty Publications from the Harold W. Manter Laboratory of Parasitology. 639.

https://digitalcommons.unl.edu/parasitologyfacpubs/639

This Article is brought to you for free and open access by the Parasitology, Harold W. Manter Laboratory of at DigitalCommons@University of Nebraska - Lincoln. It has been accepted for inclusion in Faculty Publications from the Harold W. Manter Laboratory of Parasitology by an authorized administrator of DigitalCommons@University of Nebraska - Lincoln. 


\title{
Evaluation of Some Vulval Appendages in Nematode Taxonomy
}

\author{
Lynn K. Carta, ${ }^{1,5}$ Zafar A. Handoo, ${ }^{1}$ Eric P. Hoberg, ${ }^{2}$ Eric F. Erbe, ${ }^{3}$ and William P. Wergin ${ }^{4}$ \\ ${ }^{1}$ Nematology Laboratory, United States Department of Agriculture-Agricultural Research Service, Beltsville, Maryland \\ 20705, U.S.A. (e-mail: lynn.carta@ars.usda.gov, handooz@ars.usda.gov) and \\ ${ }^{2}$ United States National Parasite Collection, and Animal Parasitic Diseases Laboratory, United States Department of \\ Agriculture-Agricultural Research Service, Beltsville, Maryland 20705, U.S.A. (e-mail: eric.hoberg@ars.usda.gov)
}

ABSTRACT: A survey of the nature and phylogenetic distribution of nematode vulval appendages revealed 3 major classes based on composition, position, and orientation that included membranes, flaps, and epiptygmata. Minor classes included cuticular inflations, protruding vulvar appendages of extruded gonadal tissues, vulval ridges, and peri-vulval pits. Vulval membranes were found in Mermithida, Triplonchida, Chromadorida, Rhabditidae, Panagrolaimidae, Tylenchida, and Trichostrongylidae. Vulval flaps were found in Desmodoroidea, Mermithida, Oxyuroidea, Tylenchida, Rhabditida, and Trichostrongyloidea. Epiptygmata were present within Aphelenchida, Tylenchida, Rhabditida, including the diverged Steinernematidae, and Enoplida. Within the Rhabditida, vulval ridges occurred in Cervidellus, peri-vulval pits in Strongyloides, cuticular inflations in Trichostrongylidae, and vulval cuticular sacs in Myolaimus and Deleyia. Vulval membranes have been confused with persistent copulatory sacs deposited by males, and some putative appendages may be artifactual. Vulval appendages occurred almost exclusively in commensal or parasitic nematode taxa. Appendages were discussed based on their relative taxonomic reliability, ecological associations, and distribution in the context of recent $18 \mathrm{~S}$ ribosomal DNA molecular phylogenetic trees for the nematodes. Characters were found to be distributed across subsets of terminal and phylogenetically distant taxa, demonstrating considerable homoplasy. Accurate definitions, terminology, and documentation of the taxonomic distribution of vulval appendages are important in evaluations of hypotheses for either parallelism and developmental constraint or convergence and adaptation.

KEY WORDS: Araeolaimida, Ascaridida, Capillariidae, character analysis, cuticle, Enoplida, functional morphology, lateral field, Oxyuroidea, phylogeny, Plectidae, Rhigonematida, Trichocephalida, Triplonchida, Spirurida.

Cuticular modifications of the external nematode vulva are frequently described in different disciplines within the nematology community by using similar terms for distinctly different morphological structures, and very different terms for what may be homologous structures or analogous features with similar cellular-histological dynamics. Morphological analyses may fail to resolve phylogeny through confusion over proper character definition, coding, or awareness of interdependence or homoplasy (Giribet, 2003). Character terminology can be critical for phylogenetic analysis and identification linked to expert systems (Diederich et al., 2000). The need to standardize terminology seems to be a universal concern among nematologists, as exemplified in surveys on the extensive variability in cuticlelayering across diverse taxa (Blaxter and Robertson, 1998; Decraemer et al., 2003). In vulval appendages, terms are often used interchangeably, so confusion occurs when images are not readily available. It is our contention that distinct structures exist that should be described and generally defined so that adjectives are

\footnotetext{
${ }^{3}$ Retired (e-mail: weekserbe@verizon.net),

${ }^{4}$ Retired (e-mail: wwergin@msn.com), and

${ }^{5}$ Corresponding author
}

not used randomly. The categories in this survey have the potential to promote the understanding of functional morphology across taxonomic disciplines. These terms can be further qualified when other studies are made to examine homology.

In nematodes the vulva is a cuticle-covered opening in the hypodermis from which eggs are laid at the ventral exterior of adult females or hermaphrodites. The shape of the opening is often a transverse slit and occasionally a longitudinal slit or symmetrical pore. Developmental biologists observed that in the Caenorhabditis elegans model system, the vulva is composed of 20 cells, epithelial cells and associated muscles essential for egg laying (Bird and Bird, 1991), that connect the hypodermis with the uterus (White, 1988). However, the division of exterior vulva and internal vagina is warranted for nematode morphology and taxonomy (Maggenti, 1981). For nematodes such as Dorylaimida, it is especially important to more precisely define the vulva as the outer cuticular region of the female invagination continuous in width with the body cuticle (De Ley et al., 1993).

Here, we describe the variations in terminology and morphology of vulval appendages with a survey of the literature and specific examples. The terms are 
descriptive for categories based on orientation, size, and tissue location, and they are not meant to imply homology. For example, the prerectum is a repeatably recognizable structure with phylogenetically diverse occurrence (Carta and Osbrink, 2005), as are wings in very diverse animals. Therefore, the most common and stable vulval appendages defined and surveyed are mapped onto trees based on current hypotheses of nematode phylogeny. We also have refined ecological associations to compare occurrence among species and higher taxa that may support useful biological predictions. Because orthologous genes can act on homologous or analogous cells (Bolker and Raff, 1996) that generate external appendages, insight into their phylogeny, variability, coordinated occurrence, and structure are necessary before relevant developmental-genetic mechanisms for these natural vulval phenotypes using a candidate gene approach can be considered (Haag and True, 2001).

\section{MATERIALS AND METHODS}

An extensive literature search was undertaken from comprehensive reviews (Chitwood and Chitwood, 1950; Maggenti, 1981; Malakhov, 1994) describing Adenophorean nematodes (Hope, 1974; Platt and Warwick, 1983, 1988; Lorenzen, 1994; Warwick et al., 1998), animalparasitic nematodes (Skrjabin, 1949, 1951, 1952, 1954), plant-parasitic and insect-parasitic nematodes (Hunt, 1993; Siddiqi, 2000), terrestrial free-living nematodes (Goodey and Goodey, 1963; Sudhaus and Fitch, 2001; Andrássy, 1983), as well as numerous individual articles on specific taxa. When a statement is derived from taxa within taxonomic compendia such as those of Siddiqi or Skrjabin, the citation is prefaced with "in." The online database at www.cabi.org, email: for Nematological and Helminthological Abstracts from PESTCABWeb, CABI Publishing, Wallingford, U.K., also was searched through monthly updates by DialogAlertServices@

dialog.com through the National Agricultural Library, Beltsville, Maryalnd, U.S.A., for the following terms through September 2008: lateral vulval membrane, vulval membrane, vulval fan, vulval flap, vulval dike, vulval alae, and epitygma(ta).

\section{Microscopy}

Some nematodes were processed for differential interference light microscopy as either heat-relaxed, live specimens (Distolabrellus veechi Anderson, 1983) or 3.2\% formaldehyde-fixed specimens (Aphelenchoides sp. and an undescribed species of Mermithidae). Other nematodes (Distolabrellus veechi, C. elegans) were processed for low temperature scanning electron microscopy (LTSEM) in distilled water according to standard procedures (Wergin et al., 1993; Carta et al., 2003). Photomicrographs were oriented with ventral side facing the top of the plates. Line figures from previous publications were traced and modified or scanned from published drawings.

\section{Phylogeny}

Three comprehensive alternative trees of nematodes were recently constructed with $18 \mathrm{~S}$ small subunit (SSU) rDNA sequences of a large number of similar taxa (Holterman et al., 2006; Smythe et al., 2006; Meldal et al., 2007). Trees of Holterman et al. (2006) and Meldal et al. (2007) were chosen as character frameworks for this study based on taxon coverage, secondary alignment strategies, Bayesian tree-making methods, and better tree resolution. The topology of 1 tree was abstracted from a Bayesian Inference tree created with 339 taxa having 2,471 aligned SSU rDNA positions from a ClustalW alignment manually edited in accordance with arthropod sequences aligned by secondary structure (Holterman et al., 2006). The topology of a second tree was abstracted from a Bayesian Inference tree created with 212 taxa having 1,167/1,884 aligned SSU rDNA characters created from a profile alignment built upon some European RNA database sequences aligned according to secondary structure; this alignment was then culled of the most ambiguously aligned positions (Meldal et al., 2007). The Holterman tree was supplemented with information on the placement of Brevibucca Goodey, 1935 and new sequence of membrane-bearing Cuticonema Sanwal, 1959 from more ribosomal and nuclear gene characters (Kiontke et al., 2007) that demanded independent placement from the Cephalobidae, and taxonomic categories were based on pre2002 taxonomic groupings. The Meldal tree was labelled with newer taxonomic categories (De Ley and Blaxter, 2002, 2004; based in part on Blaxter et al., 1998 and Aleshin et al., 1998) and older, lower level categories as appropriate. The current trees were made with MacClade version 4.05 software (Maddison and Maddison, 1992; Sinauer Associates, Inc., Sunderland, Massachusetts, U.S.A.) in which characters were traced on 2 different tree topologies to demonstrate the distribution of 3 of the most common vulval appendages of membranes, flaps, and epiptygmata in higher taxa. Life history associations were included in branches on trees to include 0 , free-living; 1 , invertebrate commensal (an important but overlooked category); 2 , invertebrate parasitic; 3 , animal parasitic; and 4, plant parasitic.

\section{RESULTS AND DISCUSSION}

\section{Nomenclature and distribution}

The names "vulval membrane" and "vulval flap" are based on the precedent set by Siddiqi (2000), where "membranes" have a primarily lateral orientation and "flaps" have a primarily parallel orientation relative to the vulval slit. An early general approach to terminology for vulval appendages was ambiguous because lateral membrane was defined as "a cuticular flap situated on both sides of the vulval slit in some nematodes. See epiptygma, "vulvar flap" (Caveness, 1964). Vulval flaps were defined as "cuticular membranes sited at both ends of the vulva. See epiptygma, lateral membrane" (Caveness, 1964). Another general description blurred the distinction among what we consider three separate structures of vulval membranes, vulval flaps, and epiptygmata"Vulval membranes (vulval flaps) occur in some 
plant-parasitic Secernentea (Paratylenchus and Hoplolaimus)" (Hirschmann, 1971). A recent compilation of designations for nematode morphological structures for identification by expert systems includes various names for 3 vulval appendages: anterior lip of vulva $=$ (ventral vulval flap); epitygmata $=$ epiptygmata $=$ (lateral membrane); lateral vulval flaps $=$ vulval membranes $=$ vulval dikes $=$ vulval alae. These authors acknowledge a right to be "wrong" about the nature and naming of a structure, and the continuing need to resolve contradictory character concepts for identification and phylogeny (Diederich et al., 2000).

Vulval appendages have been studied in some detail among animal-parasitic Strongylida. Sections through the vulval region of these nematodes reveal 3 distinct types of structures (Hoberg et al., 1993b). The first includes consistent, symmetrical, lateral cuticular "fans" internally supported by hypertrophied struts, and arising from specific regions within the lateral field. They are designated here as vulval membranes. The second comprise inconsistent, irregular, asymmetrical, body wall and cuticular "flaps" with a primary anterior to posterior orientation parallel to the vulval slit, designated here as vulval flaps. The third includes inconsistent, irregular, often lateral asymmetrical cuticular "inflations" of amorphous orientation without organized strut support, similar to vulval membranes, and probably unique to the Ostertagiinae, designated as "cuticular inflations" (Chitwood and Chitwood, 1950). Examples of these types of appendages in other taxa are discussed below and illustrated (Figs. 1-19), and some are mapped onto phylogenetic trees (Figs. 20, 21).

\section{Vulval membranes}

As used here, vulval membranes are semioval, approximately symmetrical, cuticular outgrowths lateral and perpendicular to the vulval slit. Annulation or longitudinal indentations are visible on their edges. Vulval membranes are described (Figs. 1, 7-9) with various terms in different taxa in plant parasites as "lateral vulval membranes," "lateral vulval flaps," "vulval sheaths" or "advulval flaps"; in bacterialfeeding rhabditids as "opercula," "ridge-like sculptures" or "flaps"; in insect parasitic mermithids as "wide lips flanking the vulva"; in animal-parasitic Strongylida as "bilateral vulval fans" or "fin-like processes"; and in animal-parasitic Trichocephalida as "lateral alate membranes." Among the Rhabditida, vulval membranes visible with the light microscope
(LM) have been described in Cuticonema vivipara Sanwal, 1959 (Sanwal, 1959) (Panagrolaimoidea); Operculorhabditis longespiculosa Khera, 1969 (Khera, 1969) (Mesorhabditinae) (Fig. 8); and all species of Caenorhabditis. They are quite large in Caenorhabditis sonorae Kiontke, 1997 and Caenorhabditis drosophilae Kiontke, 1997 (Kiontke, 1997). Much smaller vulval membranes in C. elegans N2 had visible annulations viewed with LTSEM (Fig. 9). Small vulval membranes also were observed with the SEM in Rhabditis (Oscheius) guentheri Sudhaus and Hooper, 1994, described as "longitudinal cuticular flaps $8-10 \mu \mathrm{m}$ long $\ldots$ at each end of the vulval slit," (Sudhaus and Hooper, 1994). An SEM view of a related free-living rhabditid nematode, Pellioditis pellio (Schneider, 1866) Timm, 1960, showed no vulval appendages (Eveland et al., 1990). Vulval membranes also are seen in the relatively primitive Tylenchina such as in Tylodorinae (Siddiqi, 2000), e.g., Coslenchus Siddiqi, 1978 (Siddiqi, 1980); Cephalenchus Goodey, 1962 (Golden, 1971) (Siddiqi, 2000); Pterotylenchus Siddiqi and Lenné, 1984 (Siddiqi and Lenné, 1984); and in one species of insect-parasitic Deladenus Thorne, 1941 out of 15 species in the genus (Shahina and Maqbool, 1992). Dolichodorus longicaudatus Doucet, 1981 is illustrated with a lateral vulval membrane (Doucet, 1981), and South American species in the related genus Belonolaimus Steiner, 1949 (syn. Ibipora), have vulval membranes (Doucet and Filisetti, 2000; Siddiqi, 2000). Vulval membranes may be found in the Criconematina, in Paratylenchus Micoletzky, 1922 (Raski, 1975a, b; Dolinski et al., 1996), and in Hemicriconemoides Chitwood and Birchfield, 1957 as "vulval sheaths" (Dasgupta et al., 1969), where they are prominent in Hemicriconemoides cocophilus (Loos, 1949) Chitwood and Birchfield, 1957 and Hemicriconemoides wessoni Chitwood and Birchfield, 1957 (Esser and Vovlas, 1990). The vulval membranes of Pratylenchus roseus Zarina and Maqbool, 1998 are unique within this genus (Zarina and Maqbool, 1998). In the adenorphorean terrestrial mermithid Tunicamermis melelonthae Schuurmans-Stekhoven, Mawson, Couturier, 1963, they are described as wide lips that flank the vulva (Poinar, 1975b).

\section{Vulval flaps}

The word "flap" in the literature is the most ambiguous term of all, because it has been used to describe what is designated here as vulval membrane, vulval flap, or epiptygma. As used here, vulval flaps 


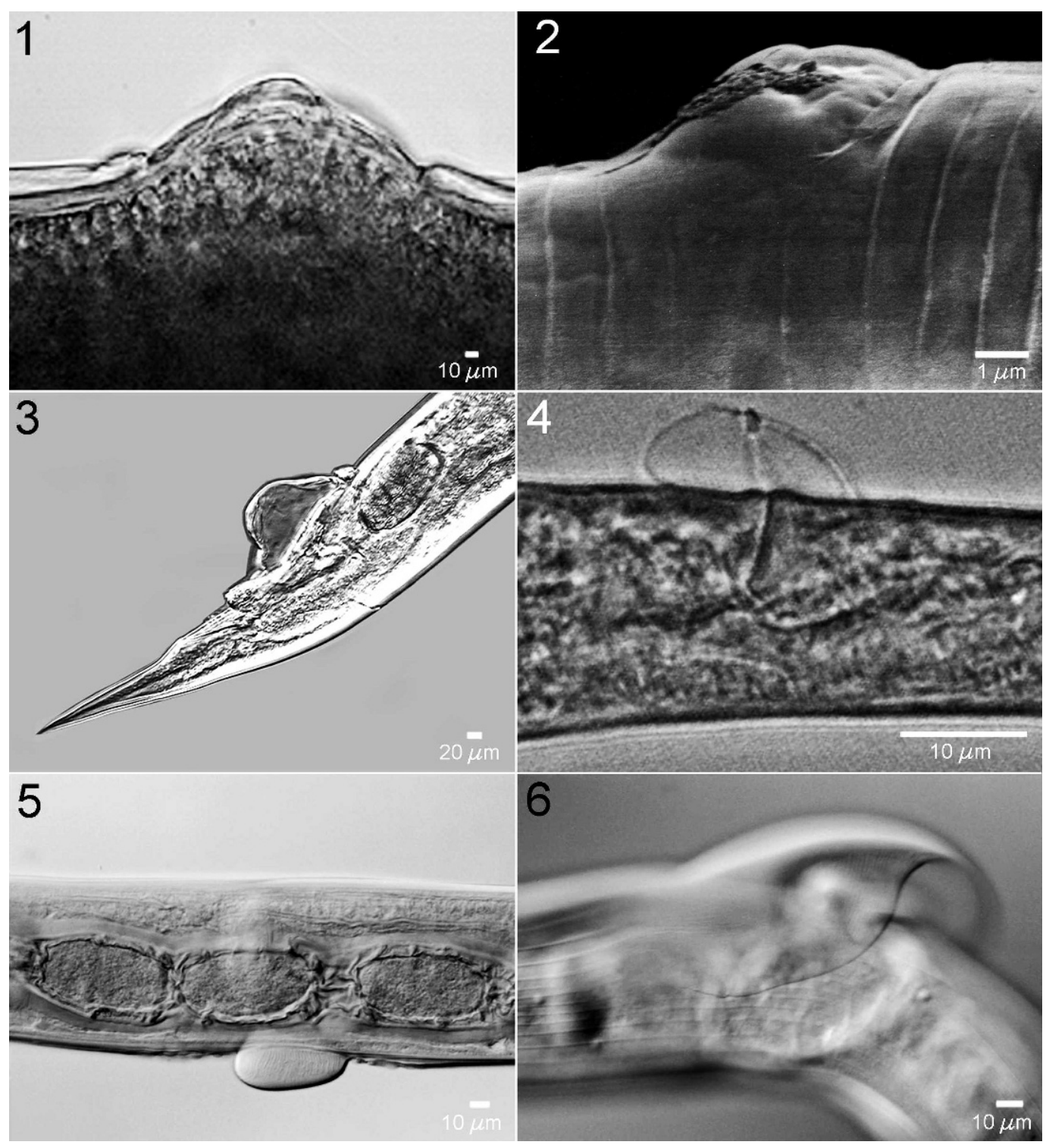

Figures 1-6. Comparative structure of vulval appendages. 1. Vulval membrane of unidentified mermithid (Mermithidae). 2. Protruded vulva with unseparated lateral cuticular seam from unmated female of Distolabrellus veechi (SEM). 3. Persistent copulatory sac of mated female, D. veechi. 4. Persistent copulatory sac of Aphelenchoides sp. 5. Vulval cuticular inflation of Hyostrongylus rubidus (after Hoberg et al., 1993a). 6. Vulval flap, Ostertagia mossi (after Hoberg et al., 1993b).

are mild-to-extreme modifications of the anterior vulval lip that show up as overhanging extensions of cuticle oriented parallel and anterior to the vulval slit (Figs. 6, 10-12). Vulval flaps were described as such among the primarily plant- or insect-parasitic Tylenchida and Aphelenchida, including the prominent structures of Rhadinaphelenchus J. B. Goodey, 1960 (Nickle, 1970); a sclerotized, jointed flap in Aphelenchoides vigor Thorne and Malek, 1968 (Thorne and Malek, 1968); and variably sized flaps in Bursaphelenchus Fuchs, 1937 (Nickle et al., 1981), where they exist in approximately one third of the known species (in Yin et al., 1998; Braasch, 2001). A small vulval flap has sometimes been observed in the tylenchid weevil parasite Elaeolenchus parthenonema Poinar, Jackson, Bell, and Wahid, 2002 after it enters the insect but not in the infective female (Poinar et al., 2002). Vulval flaps are found in some 

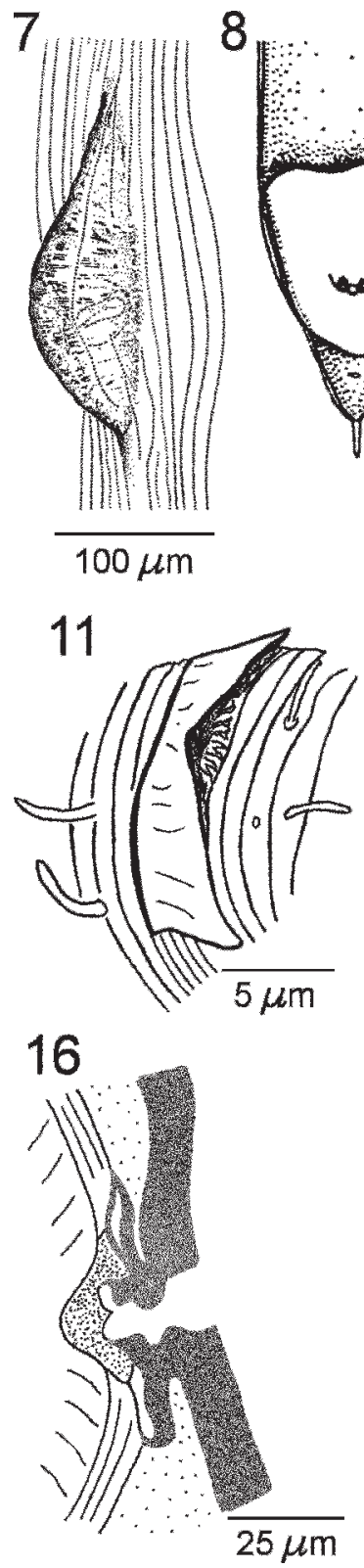

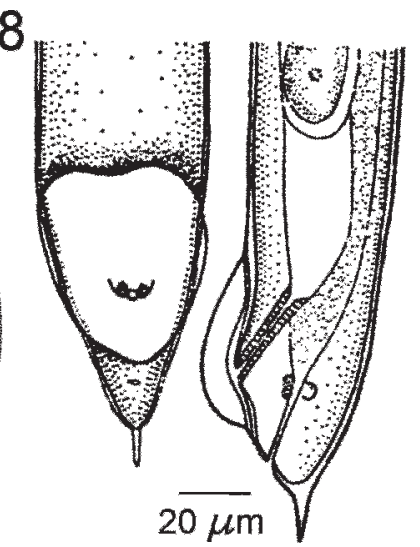

$20 \mu \mathrm{m}$

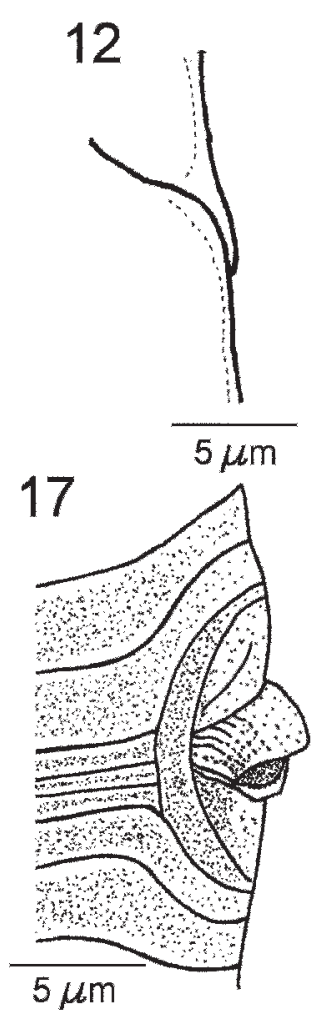

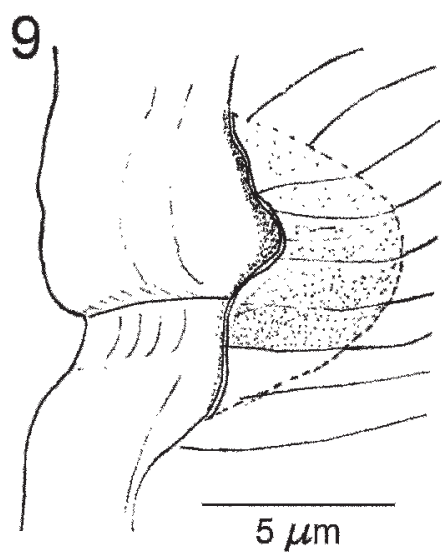

13
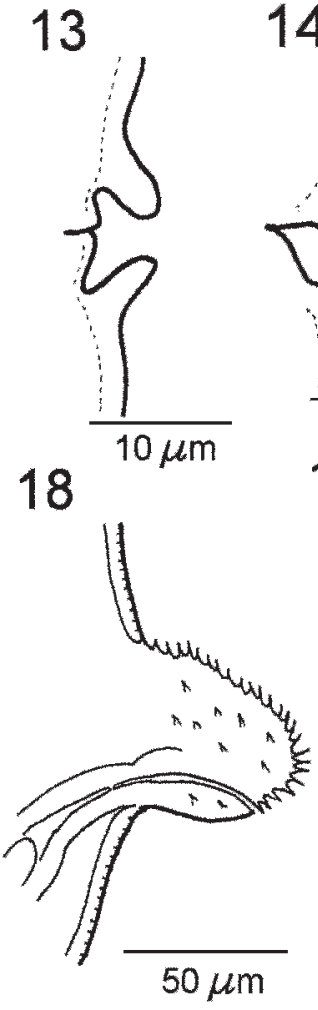

19

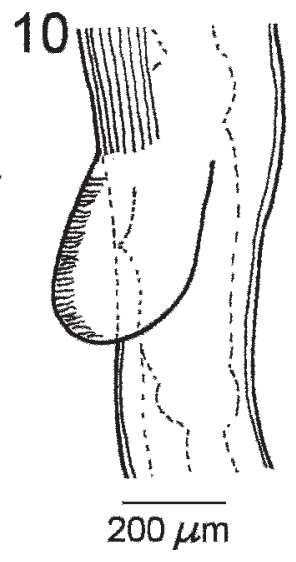

14
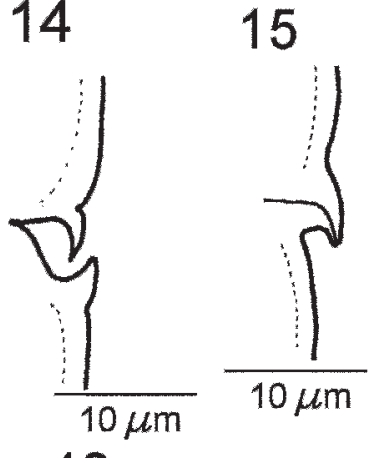

Figures 7-19. Comparative structure of vulval appendages. 7. Vulval membrane of Cooperia neitzi (after Hoberg et al., 1993c). 8. Vulval membrane of Operculorhabditis longespiculosa (after Khera, 1969). 9. Vulval membrane of of Caenorhabditis elegans. 10. Vulval flap of Ostertagia occidentalis (after Hoberg et al., 1993b). 11. Vulval flap of Epsilonema espeeli (after Verschelde and Vincx, 1994). 12. Vulval flap of Bursaphelenchus pinasteri (after Baujard, 1990). 13. Epiptygma of Steinernema ritteri (after De Doucet and Doucet, 1990). 14. Epiptygma of Hoplolaimus seinhorsti (after Sher, 1963). 15. Epiptygma of Morulaimus geniculatus (after Sauer, 1965). 16. Epiptygma of Deontostoma californicum (after Hope, 1974). 17. Double epiptygma of Plesiorotylenchus striaticeps (after Elekçioğlu, 2000). 18. Protruding vulvar appendage of Trichocephalus skrjabini (after Skrjabin, 1954). 19. Vulval ridges of Cervidellus baujardi (after Mounport et al., 2002). 


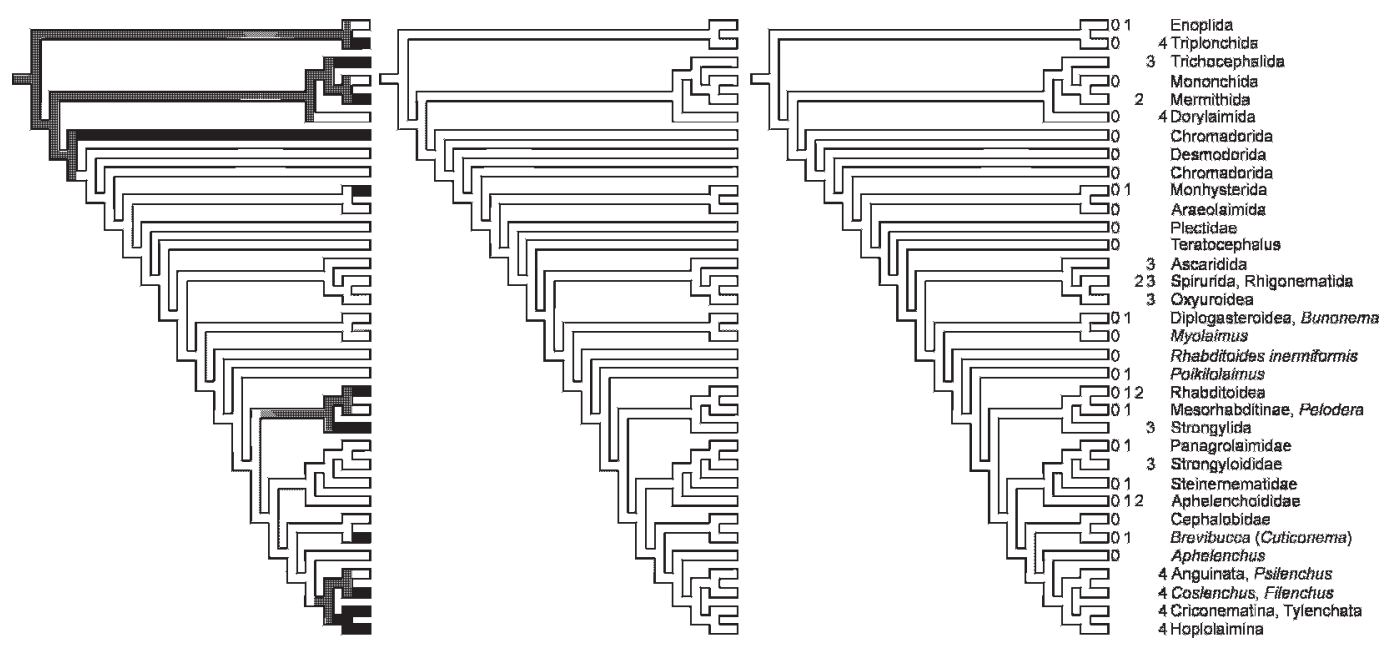

Figure 20. Phylogenetic trees for nematodes with vulval appendages (left, vulval membranes; center, vulval flaps; right, epiptygmata; Appendix 1) mapped onto one topology based on 18S SSU-rDNA molecular-based trees (after Holterman et al., 2006). Numbers before taxa signify presence but not necessarily predominance of the following life history characters: 0 , free living; 1 , invertebrate phoretic or commensal; 2, invertebrate parasitic; 3 , vertebrate parasitic; and 4, plant parasitic.

aquatic genera of insect parasitic Mermithidae that include Hydromermis Corti, 1902; Lanceimermis Artyukhovsky, 1969 (Nickle, 1972); Limnomermis Daday, 1911; Amphimermis Kaburaki \& Imamura, 1932; and Diximermis Nickle, 1972 (Nickle, 1972). Vulval flaps also were noted in a free-living marine nematode, Epsilonema espeeli Verschelde and Vincx, 1994 (Desmodoroidea) (Verschelde and Vincx, 1994). In plant parasites (Tylenchoidea), the vulval flap was described as a "vulval sleeve" in Hemicycliophora penetrans Brzeski, 1974 (Brzeski, 1974), and "lip flap" in the Ecphyadophorids (Tylenchoidea) (Siddiqi, 2000), such as Ecphyadophora sheri Raski, Koshy and Sosamma, 1982 (Raski et al., 1982).

Among animal parasites, vulval flaps are present in some Trichostrongyloidea, such as Ostertagia ostertagi (Stiles, 1892), in which the degree of bovine immune response influences the presence, size and symmetry of the flap (Michel and Sinclair, 1969; Michel et al., 1972). Vulval flaps also are found among other species and genera of the Ostertagiinae, including other species of Ostertagia Ransom, 1907 (Fig. 6) and species of Spiculoptertagia (Orloff, 1933), Mazamastrongylus Cameron, 1935, and Teladorsagia Andreeva and Satubaldin, 1954 (Hoberg et al., 1993b). Among Haemonchinae, the putative sister-group of Ostertagiinae (Hoberg and Lichtenfels, 1994; Durette-Desset et al., 1999), a considerable amount of body wall occurs in the flaps characteristic of Haemonchus contortus (Rudolphi, 1802), H. placei (Place, 1893), and H. similis
Travassos, 1914 (e.g., Das and Whitlock, 1960; Gibbons, 1979; Lichtenfels et al., 1994).

\section{Epiptygmata}

Epiptygmata (singular epiptygma) (Figs. 13-17) are cuticular protrusions on 1 or both vulval lips or the vaginal wall (Siddiqi, 2000). The smallest epiptygmata seem to be strictly cuticular, but larger epiptygmata as currently defined (Baujard et al., $1991 \mathrm{a}, \mathrm{b})$ seem to involve cuticle and 1 or more protruding cells. Within plant-parasitic Tylenchida, epiptygmata are generally small and common as in most Hoplolaimoidea and Merliniinae, and some Dolichodoroidea (5 species in Belonolaimus) (Siddiqi, 2000). However, large double epiptygmata are described in many populations of Plesiorotylenchus striaticeps Elekçioğlu, 2000 (Tylenchina, Tylenchida) (Elekçioğlu, 2000) and in Scutellonema cavenessi Sher, 1964 (Hoplolaimina, Tylenchina) (Baujard et al., 1990). These protruding lips were described previously with an inner and outer, double epiptygma composed of exocuticle and mesocuticle, but not endocuticle (DeGrisse and Roose, 1975). Double epiptygmata also are seen in more distantly related Steinernematida within multiple species of Steinernema (in De Doucet and Doucet, 1990; Stock et al., 2001). Steinernematids were classified under Rhabditida, but more recently they were placed within Tylenchina under new infraorder Panagrolaimomorpha based on 18S rDNA phylogeny (De Ley and Blaxter, 2002, 2004). 


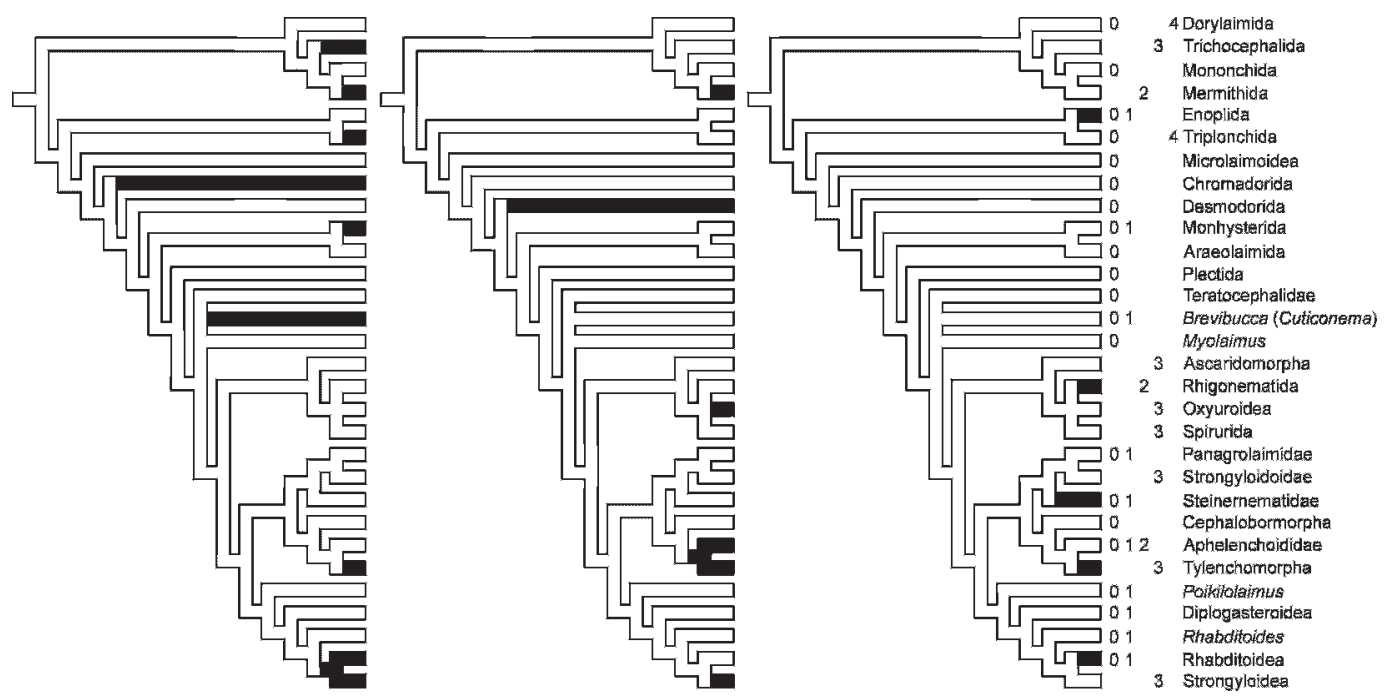

Figure 21. Phylogenetic trees for nematodes with vulval appendages (left, vulval membranes; center, vulval flaps; right, epiptygmata; Appendix 1) mapped onto one topology based on 18S SSU-rDNA molecular-based trees (after Meldal et al., 2007). Numbers before taxa signify presence but not necessarily predominance of the following life history characters: 0 , free living; 1 , invertebrate commensal; 2, invertebrate parasitic; 3 , vertebrate parasitic; and 4, plant parasitic.

It is sometimes difficult to determine from taxonomic descriptions whether hypertrophy of the body wall has occurred within overhanging, asymmetrical vulval lips, so the distinction between flaps and epiptygmata can be subtle. Within non-Secernentean nematodes, the exceptional presence of a small epiptygma-like structure is found in Deontostoma californicum Hope, 1974 (Enoplida), which has a small vulval groove and lip (Hope, 1974). Although the structure is asymmetric and seals the vulval opening, it would not be large or superficial enough to be considered a flap. Epiptygmata and vulval membranes may be present in the same nematode, as in Coslenchus costatus; Antarctenchus hooperi Siddiqi, 1980 (Siddiqi, 1980); or Rhabditis (Oscheius) guentheri (Sudhaus and Hooper, 1994). However, epiptygmata do not seem to coexist with vulval flaps, at least nominally in published descriptions. We also are unaware of any studies demonstrating a transformation between epiptygmata and flaps in individual nematodes. Although small cuticular epiptygmata are oriented parallel to the slit, like vulval flaps, their size and presence in a nematode population also may be inconsistent within a population as with projecting and nonprojecting epiptygmata in Scutellonema Andrássy, 1958 (Mekete et al., 2008), but details of this variability were not given. The vulva, vagina, and uterus seem to be stretched in an individual in which an epiptygma is not projecting, so it is unclear whether a proportion of the population did not possess epiptygmata (Mekete et al., 2008). Ambiguity also is especially apparent within structures of Hoplolaimidae and Telotylenchidae.

\section{Vulval cuticular inflations}

Irregular "cuticular inflations" (Chitwood and Chitwood, 1950) of variable orientation around the vulva exist in some individuals within species of Hyostrongylus Hall, 1921 such as Hyostrongylus rubidus (Hassall and Stiles, 1892) Hall, 1921 (Fig. 5) (Hoberg et al., 1993a). They also occur in species of Longistrongylus Le Roux, 1931, Mazamastrongylus, and Camelostrongylus mentulatus (Railliet and Henry, 1909) (Hoberg et al., 1993c). Within certain species of Spirurida, vulval inflations of the anterior lip (Digiani, 1999) or of both lips occur, but this feature was not included in a species-level parsimony character analysis (Zhang et al., 2003). Cuticular inflations due to fluid expansion in the medial cuticle layer near the bacillary bands in capillariid whipworms (Wright, 1975) are not generally associated with the vulva, although some of these species have everted vulvae (Lanfredi et al., 1995).

\section{Protruding vulvar appendages}

These are nonartifactual vulval elaborations in which part of the female reproductive system evaginates, with different degrees of exposure of the vulva, vagina, or uterus, depending on species 
(Lanfredi et al., 1995). They may have variable shapes, including funnel-shaped, tubular (Lanfredi et al., 1995), or globular (Ching, 1990). These structures also are known as "protruding vulvar folds" (Kalia and Gupta, 1984), or even "noncuticular, transparent formations" (terminology used in Skrjabin, 1954). These structures that represent partially or fully everted gonadal tissue are described in adenophorean capillariid Trichocephalida as large toroidally "protruding membranes" as in Capillaria caudinflata Molin, 1858 (Fig. 18) (Skrjabin, 1954). The vulvar appendage in Capillaria ohbayashi Justine, 1992 was variably present and may not exist in some individuals within the species (Justine, 1992), probably due to their generation on oviposition (Lanfredi et al., 1995). In secernentean pinworms (Heteroxynematidae, Oxyuroidea) there are "beak-like" structures composed of uterus and surrounding, hypertrophied vulval lips that protrude from the body that are not artifacts of fixation (Hoberg and Pilitt, unpublished data).

Highly protruding vulval lips were described in proposed new genera Eminensia Mahajan, 1980 and Evaginorhabditis Sultan, Kaul and Chhabra, 1985, but they were more likely artifacts of fixation in a relatively weak morphological structure (De Ley, 1995). Vulval lips also protrude normally even before egg laying in Distolabrellus veechi Anderson, 1983 (Fig. 2), but they often protrude with age in many rhabditids and some tylenchids, e.g., insect-parasitic Deladenus (Chitambar, 1991). The thickness and protrusion actually seemed to be characteristic of species such as Aphelenchus avenae Bastian, 1865 but not of the related Aphelenchus isomerus Anderson and Hooper, 1980 (Anderson and Hooper, 1980). Unusual evaginated uteri, in which vulval and body cuticle were left behind, were found in secernentean tylenchid Sphaerularioidea (Siddiqi, 2000) and would be distinct from all structures mentioned above.

\section{Miscellaneous cuticular vulval appendages}

In females of Cervidellus baujardi Mounport, Bostrom and Villenave, 2002 (Rhabditida: Cephalobidae), protruding tessellate ridges along the body had a concave modification perpendicular to each side of the vulval slit for the length of 16 annules to form a lateral cuticular ridge. This delimited a spindle-shaped window above a sunken vulva region (Fig. 19). This structure was unique among species in the genus (Mounport et al., 2002) and is here denoted a "lateral vulval ridge."

Another peri-vulval cuticle modification of villifilled pits occurred in parasitic females of Strongy- loides fuelleborni kelleyi von Linstow, 1905 (species in Viney et al., 1991). This species caused potentially fatal human infections in New Guinea and was distinguished from the less pathogenic Strongyloides fuelleborni fuelleborni von Linstow, 1905 (species in Viney et al., 1991) in African primates by their presence. The paired pits were 90 degrees lateral to the vulva, extending the length of 12 distorted annules (Viney et al., 1991). Small subunit18S rDNA sequences demonstrated that the morpho-"subspecies" from New Guinea actually resided in a separate tree clade, close to Strongyloides papillosus Chang and Graham, 1957 from various domestic animals (Dorris et al., 2002). Thus, the pits seemed to be convergences associated with primate hosts. Host immunity is associated with reduced body and gonad size in Strongyloides ratti Nigon and Roman, 1952 and damage to Strongyloides stercoralis (Bavay, 1876) Stiles and Hassall, 1902 (Wilkes et al., 2004).

Another vulva-associated structure is a cuticular saccate protrusion that acts like a spermatophore-like capsule to catch sperm from males that lack spicules (Fürst von Lieven et al., 2005). This was described as a vulval cuticular sac in related Deleyia Holovachov and Boström, 2006 (Holovachov and Boström, 2006).

\section{Copulatory sacs or plugs}

The copulatory sac (Chitwood, 1929), more recently designated as the copulatory plug (Barker, 1994) is a translucent to opaque protrusion around the vulva deposited by males during copulation via male cement glands. This plug secretion is often confused with a cuticular vulval membrane (Figs. 3, 4). However, upon more extensive survey, multiple sacs may be found (Chitwood, 1929); the margins are often irregular (Gerber and Giblin-Davis, 1990); no cuticular markings are evident; and the sac is sticky to bacteria, sperm, or a needle. Spicules and eggs can move through an obscure canal or punctum within the sac (Chitwood, 1929). The sacs were observed without bacteria and compared with unmated females with many bacteria around the vulva. The caudal alae of Pelodera strongyloides (Schneider, 1860) Schneider, 1866 also shaped the final form of the plug (Wagner and Seitz, 1983). The ability of $P$. strongyloides to dissolve a tunnel within the sac to reinseminate the female (Chitwood, 1929) led to speculation that the male may have release glands allowing separation (Sarr et al., 1987). Plugs were variably present in some strains of $C$. elegans (Maupas, 1900) Dougherty, 1953 (Barker, 1994) and a few other rhabditids, but they may not be as 
obvious at the LM level as in the larger genera. A yellow liquid accumulates in the seminal vesicle of mating males and is secreted after insemination (Barker, 1994). Copulatory sacs may be viewed with various stains such as those used for plant-parasitic nematode egg matrices (Southey, 1986). Persistent copulatory sacs are prominent in rhabditids Teratorhabditis (Osche, 1952) Dougherty, 1955 (Gerber and Giblin-Davis, 1990), Cruznema Artigas, 1927 (Andrássy, 1983), Distolabrellus (Anderson, 1983), Pelodera Schneider, 1866, Cephalobus Bastian, 1865 (Chitwood, 1929), Acrobeloides (Cobb, 1924) (Jairajpuri and Azmi, 1977), Acrobeles von Linstow, 1877 (Steiner, 1929), and in the female generation of Heterorhabditis Poinar, 1975 (Poinar, 1975a). Such structures, occurring as amorphous, irregular, darkly pigmented accumulations capping the vulva also are noted among some Strongylida, including species of Oesophagostomum Molin, 1861. Copulatory sacs also have been noted (Sarr et al., 1987) in plantparasitic Scutellonema cavenessi Sher, 1964 (Demeure et al., 1980), and the marine nematode Desmodora schulzi Vincx, 1983 (Vincx, 1983).

The ambiguity of cuticular and secreted vulval appendages is partly due to the often-symmetric shape and refractive edge of the copulatory sac. The confusion also may be due to the close phylogenetic relationship of nematodes with both structures. One putative vulval membrane of the monotypic genus Operculorhabditis Khera, 1969 (Rhabditida) that is briefly described in the literature (Khera, 1969) can be confused even by seasoned taxonomists with the copulatory sac of the rhabditids mentioned above (Fig. 8). Similarly, within the Aphelenchina, in which true vulval flaps also occur, an Aphelenchoides Fischer, 1894 species has a copulatory sac similar in appearance to a vulval membrane except for the punctum and lack of annulation (Fig. 4). Copulatory sacs or plugs are common within some females of Rhigonematida in which they may anchor ephemeral spermatophores from the male and exclude other males. Vulval flaps in some species seemed to aid in the protective function proposed for the plugs (Hunt, 2001).

\section{Phylogenetic utility}

Due to morphological and nomenclatural variability, vulval appendages must be described carefully in nematode taxonomy. Among Trichostrongylidae, occurrence of flaps exhibits homoplasy with some representation among distantly related Cooperiinae and in the putative sister-groups Ostertagiinae + Haemonchinae (Hoberg and Lichtenfels, 1994; Dur-
ette-Desset et al., 1999). Vulval flaps are variable among haemonchines and considered unreliable for separating species in Haemonchus Cobb, 1898 and Ashworthius Le Roux, 1933 (e.g., Lichtenfels et al., 1994; Dróżdż et al., 1998), or among the diversity of ostertagiine nematodes in which they are observed. Similarly, vulval membrane-like structures described as cuticular inflations also are unreliable in the species Hyostrongylus rubidus (Fig. 5) and Hyostrongylus kigeziensis Durette-Desset, Ashford, Butynski, and Reid, 1992 (Hoberg et al., 1993a). Vulval flaps and vulval membrane-cuticular inflations are occasionally characteristic of these species, often in different proportions within populations (Gibbons, 1987), but they are not reliable characters. Not only are the vulval flaps variable in Haemonchus, and the ostertagiines Hyostrongylus, Ostertagia, Spiculopteragia, and Teladorsagia, they are generally variable in occurrence within genera and among conspecifics across the Ostertagiinae. Thus, they are considered unreliable even for species-level identification. However, their variable phenotypes have been used to characterize ecotype populations that may represent incipient species (Whitlock and Le Jambre, 1981).

Vulval membranes seem to be consistently present in a few species within the animal-parasitic Cooperinae (Strongylida), as well as some primitive plantparasitic species within the Tylenchida. Vulval membranes (described as "bilateral vulval fans") are consistent features easily seen with the LM in the related animal parasites Parostertagia heterospiculum Schwartz and Alicata, 1933; Cooperia neitzi Mönnig, 1932 (Fig. 7); Cooperia verrucosa Mönnig, 1932; and Cooperia okapi Leiper, 1935 (Hoberg et al., 1993c); and in bacterial-feeding facultative or phoretic parasites Rhabditis (Choriorhabditis) dubia Bovien, 1937 (Osche, 1952) (Sudhaus and Kühne, 1989) and Rhabditis (Caenorhabditis) sonorae (Sudhaus and Kiontke, 1996). In Rhabditis (Oscheius) guentheri (Sudhaus and Hooper, 1994) and Caenorhabditis elegans, they are only easily seen with the SEM. However, in the monotypic genus Operculorhabditis Khera, 1969 membranes are described as deciduous, an exceptional condition for cuticular membranes in the literature. These may not be cuticular structures, because annular incisures are not included on the drawing. In addition, variability among the 7 collected females is unknown because original material was not available, and the species has not been found again. In face view, there also seems to be an exceptional ventral extension connecting the "membranes" (Khera, 1969) that 
could be persistent copulatory sacs. Sometimes deciduous copulatory sacs are present in the morphologically similar genus Teratorhabditis.

Although the presence of an epiptygma-like vuval flap in Epsilonema espeeli Verschelde and Vincx, 1994 (Chromadorida) is constant, the shape is not (Verschelde and Vincx, 1994). Epiptygmata are fairly common and reliable in some groups of nematodes with a central vulva and two-armed gonads such as in the Dolichodoroidea, Hoplolaimidae, Psilenchidae (Siddiqui, 1986), and Steinernematida (De Doucet and Doucet, 1990). However, the dolichodoroid nematode Melinius adakensis Bernard, 1984 (Telotylenchidae) has considerable shape variation of epiptygma either on the dorsal or ventral lip (Bernard, 1984). In Dolichodoroidea such as Ibipora Monteiro and Lordello, 1977 (Belonolaimidae), epiptygma coexist with vulval membranes (in Siddiqi, 2000). In Rhabditidae (Sudhaus and Hooper, 1994) epiptygma are less common, but here they also may coexist with membranes. However, it was noted that epiptygmata on the posterior lip (exceptionally on the anterior lip) of Rhabditis (Oscheius) guentheri were not apparent in live, but only fixed material (Sudhaus and Hooper, 1994). This observation also might apply to some live parasitic nematodes for which observations and measurements are often not made until material is fixed.

\section{Phylogenetic patterns of individual and combined characters}

Associations of vulval appendages of different nematode taxa can be visualized through the mapping of characters on phylogenetic trees as depicted in Figs. 20 and 21. It was not appropriate to use the "concentrated changes" test for character correlation of MacClade because this phylogeny was not fully resolved to reflect the frequent character reversals at the species level. These trees are descriptive; the true incidence of any character correlations may be possible in the future when more detailed phylogenies become available among all the relevant taxa.

There is a unique acquisition of vulval membranes occurring 5 (Fig. 20) to 7 (Fig. 21) times in the listed higher level taxonomic categories, of vulval flaps occurring 5 (Fig. 20) to 6 (21) times, and epiptygmata 5 times (Figs. 20, 21). These structures occur most often in terminal taxa where phylogenetic resolution is generally not available. Examples of exceptional vulval membranes include 1 insect-parasitic tylenchid Deladenus species among 15 (Shahina and Maqbool, 1992); 1 plant-parasitic Pratylenchus Filipjev, 1936 (Zarina and Maqbool, 1998) species among more than
60 species (Ebsary, 1991); and 1 Cuticonema (Rhabditida) among the entire Panagrolaimoidea (Sanwal, 1959). The relatively shallow branching pattern of vulval appendages also was also seen in recent species-and generic-level phylogenies. Among species of Steinernema Travassos, 1927, epiptygmata arose at least 4 times (Stock et al., 2001). Vulval membranes arose in Rhabditidae at least 3 times (Sudhaus and Kiontke, 1996).

\section{Cuticle ridges and lateral field}

Well-developed vulval appendages in some species may sometimes be associated with a recognizable pattern of cuticular features such as lateral field incisures or lateral ridges. Among the 28 species of plant-parasitic and insect-phoretic Bursaphelenchus (Aphelenchida) in European conifers, 4 groups are distinguished in part by 2 to 4 , or 6 lateral incisures associated with presence and size of vulval flaps. The largest flaps occur in taxa having 3 lateral lines (Braasch, 2001). The 6 genera within plant-parasitic Merliniinae (Tylenchina) have 6 lateral incisures and epiptygmata, but epiptygmata are generally lacking in related genera with fewer incisures (in Siddiqi, 2000). Among the other genera of Tylenchorhynchinae with prominent longitudinal lines and ridges, Mulkorhynchus Jairajpuri, 1988 (syn. Dolichorhynchus Mulk and Jairapuri, 1974) has vulval membranes and 4 incisures, but there are no membranes in related Prodolichorhynchus Jairajpuri, 1985 with 2 incisures (in Jairajpuri and Hunt, 1984).

Cuticular ridges are strongly associated with appendages in some taxa, in which case appendages may be inversely associated with lateral field incisures. Eutylenchus Cobb, 1913 (Tylenchina) has vulval membranes, with lateral, mid-dorsal, and midventral ridges and no lateral incisures (Brzeski, 1996), but related Atylenchus Cobb, 1913 lacks vulval appendages and ridges but has lateral incisures (Siddiqi, 2000). In South American species of Belonolaimus (syn. Ibipora, Tylenchina), 6 incisures occur with lateral membranes and small epiptygmata, whereas in species lacking membranes but having small epiptygmata, only 1 incisure exists (Siddiqi, 2000). Within a recent phylogeny of Caenorhabditis, Caenorhabditis sonorae Kiontke, 1997 had a smooth lateral field without incisures and moderately developed vulval membranes (Kiontke, 1997), both of which were unusual in this genus (Sudhaus and Kiontke, 1996). In trichostrongylid animal parasites, there are more midbody synlophe ridges and larger vulval membranes in Cooperia nietzi and $C$. 
verrucosa than in C. okapi (Hoberg et al., 1993c). In distantly related trichostrongylid stomach worms (Haemonchinae) possessing large, irregular flaps, Haemonchus similis has 4 more nonlateral ridges at midbody that extend more posteriorly than in related $H$. placei and $H$. contortus. These more extensive ridges are associated with a more complex vulval structure in which the vulval slit actually resides within the flap. In contrast, $H$. placei and $H$. contortus have less elaborate flap lobes anterior to the vulval slit, and synlophe ridges do not extend very far posteriad from the cervical zone (Lichtenfels et al., 1994). Variation among haemonchines is apparent, however, because both Haemonchus horaki Lichtenfels, Gibbons and Boomker, 2001 and Ashworthius patriciapilittae Hoberg, Abrams, Carreno and Lichtenfels, 2002 have a synlophe extending to near the caudal extremity, and relatively simple vulval flaps (Lichtenfels et al., 2001; Hoberg et al., 2002). The exceptional vulval membranes in Aulolaimus (Chromadorida) are associated with a fairly high number of longitudinal ridges within the genus (38 within a range of 12-50) (in Shahina et al., 1996). These associated ridge, lateral field, and appendage features seem to indicate some type of structural coordination within all these diverse taxa.

Besides well-developed cuticular longitudinal ridges, a tendency toward cuticle loosening is notable especially among plant-parasitic Tylenchidae, Criconematidae, and Trichodoridae that possess vulval membranes. In Hemicriconemoides, 7/46 species have membranes (designated "lateral cuticular flaps" in Siddiqi, 2000), and a sheath composed of a second cuticular layer; both males and females have lateral fields (Esser and Vovlas, 1990). However, there are no membranes in related species within the Criconematinae and Macroposthoniinae in which females lack lateral fields and sheaths (Brzeski et al., 2002a, b).

\section{Vulva position}

Within plant-parasitic Paratylenchus Micoletzky, 1922, the position of the vulva is associated with the degree of development of vulval membranes. A survey (Appendix 2) based on a comprehensive compendium of species (Esser, 1992) showed 64/71 Paratylenchus species with vulval membranes, and 23/41 of related Gracilacus Raski, 1962 species with membranes. Species that lacked membranes with morphometric values for vulval distance from anterior body lengths of Vulva\% less than $80 \%$, and those with ranges more than $80 \%$ had well developed appendages. A comprehensive phylogeny of these genera based on indepen- dent characters is not yet available to assess possible vulval membrane reversals within this group.

For most other taxa, vulval position and appendage presence is not so closely linked, especially at higher taxonomic levels. Although Cuticonema (Panagrolaimidae) and many primitive Tylenchina with vulval membranes have posterior vulval positions, more phylogenetically derived species in Antarctenchus (Psilenchidae), Neodolichorhynchus (Mulkorhynchus), and Scutylenchus (Dolichodoridae, Tylenchorhynchidae) have vulval membranes with approximately medial vulvas (in Siddiqi, 2000). Vulval membranes in animal-parasitic Trichostrongyloidea are associated with posterior vulvas (in Skrjabin, 1952), whereas in related insect-associated Rhabditida, the 4 species with cuticular membranes have medial vulvas. Vulvae are often anteriorly positioned in parasitic Ascarida, Spirurida, and Bunostominae (Strongylida, Ancylostomoidea) that consistently lack vulval cuticular appendages. In animal-parasitic Oxyuroidea (Oxyurata) in which vulvae may reside in any region of the body, the single instance of a vulval flap was on a posterior vulva (Skrjabin, 1951). In other oxyurids as well as capillariids with protruding vulval folds, the vulva is in the anterior part of the body (in Skrjabin, 1954). Where epitygmata exist in Tylenchida and Rhigonematida, the vulva is slightly posterior to midbody. Although animal parasitic Strongyloides stercoralis (Bavay, 1876) Stiles and Hassall, 1902 does not possess the primary vulval appendages, the peri-vulval pits associated with the parasitic female are associated with a more posterior vulva than the freeliving form (Speare, 1989).

\section{Parasitism and ecology}

Based on mapping of parasitism onto the small subunit (18S) rDNA phylogenetic tree for nematodes, associations with plants arose independently at least 3 times, and animal parasitism arose at least 6 times (Dorris et al., 1999). When vulval appendages are superimposed onto updated trees of related taxa (Fig. 20, 21 based on Holterman et al., 2006), they seem closely associated with parasitism, phoresis, or commensalism. In some cases, it has not been clearly established that vulval appendages are consistent features of a species because of limited sampling and inability to place specimens in culture. Because some vulval appendages represent inconsistent responses to a host immune challenge, and most are species-level phenomena of parasites, host factors are hypothetical inducers and selectors of those characters that do become fixed. Environmental estrogens in particular 
may be involved in fixation of epigenetic characters in vertebrates (Guerrero-Bosagna et al., 2005) and also may be important in invertebrates. Both Caenorhabditis and Panagrellus have estrogen receptors (Hood et al., 2000). Although bacterial-feeding Rhabditida are not strict parasites, nearly all have dauer larvae, and like other invertebrate symbionts "they face the same transmission problems and other pressures as those acting on parasites" (Poulin, 1998). In Rhabditida, the greatest development of vulval membranes is seen in 2 species with a relatively unique preparasitic adaptation: Caenorhabditis drosophilae and Choriorhabditis dubia (Rhabditida, Rhabditoidea) have dauer larvae requiring fly contact to mature (Kiontke, 1997). These prominent membranes may have evolved in response to their phoretic associate/facultative host. Host factors modulate the degree of flap size in Ostertagia ostertagi (Rhabditida, Trichostrongylidae) (Michel et al., 1972). The capacity of nematode cuticle to expand between molts (Lee, 2002), in contrast to the rigid cuticle and saltational growth of insects (Knight et al., 2002) is well suited to localized expansion in an immune response. Nematode cuticle also facilitates parasitism in its ability to shed and quickly repair the surface coat after immune assault (Blaxter et al., 1992).

Caenorhabditis species with the largest vulval membranes have a phoretic association with insects, and those with the smallest are associated with mollusks (Sudhaus and Kiontke, 1996). Besides possible host influence, environmental factors also may be important. Reports of fungi parasitic or commensal with snails are limited (Porter, 1986), whereas insects and plants (Alexopoulos et al., 1996; Blackwell, 2000) have many reported fungal associates. Where vulval appendages are common among aphelenchoidid nematodes, most species are free-living on fungi, aside from their associations with plants or insects (Hunt, 1993). Interference with thigmotropism, or contact-guidance, of fungi toward host surface vulnerabilities (Gow, 2004) might be one benefit of these appendages toward competing fungi in the environment.

Definitions for specific characters and the taxonomic distribution of vulval appendages could be useful for testing hypotheses of parallelism reflecting developmental constraint, or convergence resulting from adaptation (Yoon and Baum, 2004) such as might occur in nematode-microorganism, hostparasite, or male mating interactions. Details of the genetic and histological basis of vulval morphogenesis continue to accumulate in membrane-bearing $C$. elegans (Sharma-Kishore et al., 1999; Dalpé et al., 2005) and appendage-free Pristionchus pacificus
(Kolotuev and Podbilwicz, 2004). With this background, relevant developmental, behavioral, and ecological factors might be evaluated in taxa with vulval appendages for testing hypotheses.

\section{ACKNOWLEDGMENTS}

We thank Donna Ellington and Sharon Ochs of the Nematology Laboratory, and Christopher Pooley, Soybean Genomics and Improvement Lab, USDAARS for technical help. Special thanks are extended to Maureen Barr and Paul Sternberg for sharing unpublished visual information on C. elegans. Mention of trade names or commercial products in this publication is solely for the purpose of providing specific information and does not imply recommendation or endorsement by the U.S. Department of Agriculture.

\section{LITERATURE CITED}

Aleshin, V. V., O. S. Kedrova, I. A. Milyutina, N. S. Vladychenskaya, and N. B. Petrov. 1998. Relationships among nematodes based on the analysis of $18 \mathrm{~S}$ rRNA gene sequences: molecular evidence for monophyly of chromadorian and secernentean nematodes. Russian Journal of Nematology 6:175-184.

Alexopoulos, C. J., C. W. Mims, and M. Blackwell. 1996. Introductory Mycology, 4th ed. Wiley, New York. $868 \mathrm{pp}$.

Anderson, R. V. 1983. Description of Distolabrellus veechi n. gen., n. sp. (Nematoda: Rhabditidae). Journal of Nematology 15:70-75.

Anderson, R. V., and D. J. Hooper. 1980. Diagnostic value of vagina structure in the taxonomy of Aphelenchus Bastian, 1865 (Nematoda: Aphelenchidae) with a description of A. (Anaphelenchus) isomerus n. subgen., n. sp. Canadian Journal of Zoology 58:924-928.

Andrássy, I. 1983. A Taxonomic Review of the Suborder Rhabditina (Nematoda: Secernentia). ORSTOM, Paris, France. 241 pp.

Barker, D. M. 1994. Copulatory plugs and paternity assurance in the nematode Caenorhabditis elegans. Animal Behavior 48:147-156.

Baujard, P. 1990. Trois nouvelles espèces de Bursaphelenchus (Nematoda: Tylenchida) et remarques sur le genre (Nemata: Hoplolaimidae) Revue de Nématologie 3:167-177.

Baujard, P., P. Castillo, M. Doucet, B. Martiny, D. Mounport, and A. Ndiaye. 1991a. Variabilité intra- et interspécifique des structures cuticulaires externes dans le genre Aorolaimus Sher, 1963 (Nemata: Hoplolaimidae). Systematic Parasitology 19:195-213.

Baujard, P., D. Mounport, and B. Martiny. 1991b. Study of external cuticular structures in a population of the nematode Hoplolaimus seinhorsti (Nemata: Hoplolaimidae). Afro-Asian Journal of Nematology 1:19-22.

Baujard, P., D. Mounport, B. Martiny, and A. Ndiaye. 1990. Observations en microscopie électronique à balayage sur deux espèces du genre Scutellonema 
Andrássy, 1958 (Nemata: Hoplolaimidae). Revue de Nématologie 13:351-360.

Bernard, E. C. 1984. Hoplolaimoidea (Nematoda: Tylenchida) from the Aleutian islands with descriptions of four new species. Journal of Nematology 16:194-203.

Bird, A. F., and J. Bird. 1991. The Structure of Nematodes. 2nd ed. Academic Press, New York. 316 pp.

Blackwell, M. 2000. Terrestrial life-fungal from the start? Science 289:1884-1885.

Blaxter, M. L., P. De Ley, J. R. Garey, L. X. Liu, P. Scheldeman, A. Vierstaete, J. R. Vanfleteren, L. Y. Mackey, M. Dorris, L. M. Frisse, J. T. Vida, and W. K. Thomas. 1998. A molecular evolutionary framework for the phylum Nematoda. Nature 392:71-75.

Blaxter, M. L., A. P. Page, W. Rudin, and R. M. Maizels. 1992. The nematode surface coat: actively evading immunity. Parasitology Today 8:243-247.

Blaxter, M. L., and W. M. Robertson. 1998. The cuticle. Pages 25-48 in R. N. Perry and D. J. Wright, eds. The Physiology and Biochemistry of Free-Living and PlantParasitic Nematodes. CABI Publishing, St. Albans, U.K. 438 pp.

Bolker, J. A., and R. A. Raff. 1996. Developmental genetics and traditional homology. Bioessays 18:489-494.

Braasch, H. 2001. Bursaphelenchus species in conifers in Europe: distribution and morphological relationships. Bulletin OEPP 31:127-142.

Brzeski, M. W. 1974. Taxonomy of Hemicycliophorinae (Nematoda, Tylenchida). Zeszyty Problemowe Postepow Nauk Rolniczych 154:237-330.

Brzeski, W. M. 1996. On the genus Eutylenchus Cobb, 1913 (Nematoda: Tylenchidae). Nematologica 42:1-8.

Brzeski, M. W., Y. E. Choi, and P. A. A. Loof. 2002a. Compendium of the genus Criconemoides Taylor, 1936 (Nematoda: Criconematidae). Nematology 4: 325-339.

Brzeski, M. W., P. A. A. Loof, and Y. E. Choi. 2002b. Compendium of the genus Mesocriconema Andrássy, 1965 (Nematoda: Criconematidae). Nematology 4: 341-360.

Carta, L. K., and W. Osbrink. 2005. Rhabditis rainai $\mathrm{n}$. sp. (Nematoda: Rhabditida) associated with the Formosan subterranean termite, Coptotermes formosanus (Isoptera: Rhinotermitidae). Nematology 7:863-879.

Carta, L. K., W. P. Wergin, E. F. Erbe, and C. A. Murphy. 2003. A comparison of low temperature and ambient temperature SEM for viewing nematode faces. Journal of Nematology 35:78-81.

Caveness, F. E. 1964. A glossary of nematological terms. The Pacific Printers, Ibadan, Nigeria. 68 pp.

Ching, H. L. 1990. Some helminth parasites of dunlin (Caldris alpina) and western willet (Catoptrophorus semipalmatus inornatus) from California. Journal of the Helminthological Society of Washington 57:44-50.

Chitambar, J. J. 1991. On the genus Deladenus Thorne, 1941 (Nemata: Allantonematidae). Review of the mycetophagous stage. Revue de Nématologie 14:427-444.

Chitwood, B. G. 1929. Notes on the copulatory sac of Rhabditis strongyloides Schneider. Journal of Parasitology 15:282-283.

Chitwood, B. G. and M. B. Chitwood. 1950. The reproductive system. Pages 136-159 in B. G. Chitwood and M. B. Chitwood, eds. Introduction to Nematology. University Park Press, Baltimore, Maryland.
Coomans, A. 1977. Evolution as a basis for the systematization of nematodes - a critical review and exposé. Nematologica 23:129-136.

Dalpé, G., L. Brown, and J. G. Culotti. 2005. Vulva morphogenesis involves attraction of plexin 1-expressing primordial vulva cells to semaphorin la sequentially expressed at the vulva midline. Development 132:1387-1400.

Das, K. M., and J. H. Whitlock. 1960. Subspeciation in Haemonchus contortus (Rudolphi, 1803) Nemata, Trichostrongyloidea. Cornell Veterinarian 50:182-197.

Dasgupta, D. R., D. J. Raski, and S. D. Van Gundy. 1969. Revision of the genus Hemicriconemoides Chitwood and Birchfield, 1957 (Nematoda: Criconematidae). Journal of Nematology 1:126-145.

Decraemer, W., E. Karanastasi, D. Brown, and T. Backeljau. 2003. Review of the ultrastructure of the nematode body cuticle and its phylogenetic interpretation. Biological Reviews 78:465-510.

De Doucet, M. M. A., and M. E. Doucet. 1990. Steinernema ritteri $\mathrm{n}$. sp.: (Nematoda: Steinernematidae) with a key to the species of the genus. Nematologica 36:257-265.

De Grisse, A., and D. Roose. 1975. The ultrastructure of the vulva region in Scutellonema cavenessi Sher, 1963 (Nematoda: Hoplolaimidae). Mededelingen Rijksfaculteit Landbouwwetenschappen te Gent 40:501-510.

De Ley, P. 1995. Systematics of Rhabditida and Diplogasterida; Anatomy, Key and References. International Nematology Course, University of Ghent, Ghent, Belgium. 73 pp.

De Ley P., and M. L. Blaxter. 2002. Systematic position and phylogeny. Pages 1-30 in D. Lee, ed. The Biology of Nematodes. Taylor and Francis, London, U.K. $635 \mathrm{pp}$.

De Ley, P., and M. Blaxter. 2004. A new system for Nematoda: combining morphological characters with molecular trees, and translating clades into ranks and taxa. Pages 633-665 in H. Ferris, ed. Nematology Monographs and Perspectives, Volume 2. Brill, Leiden, The Netherlands. 866 pp.

De Ley, P., P. A. A. Loof, and A. Coomans. 1993. Terrestrial nematodes from the Galápagos Archipelago II: redescription of Aporcelaimellus obtusicaudatus (Bastian, 1865) Altherr, 1968, with review of similar species and a nomenclature for the vagina of Dorylaimida (Nematoda). Biologie 63:13-34.

Demeure, Y., C. Netscher, and P. Quénéhervé. 1980. Biology of the plant-parasitic nematode Scutellonema cavenessi Sher, 1964: reproduction, development and life cycle. Revue de Nématologie 3:213-225.

Diederich, J., R. Fortuner, and J. Milton. 2000. A uniform representation for the plan of organisation of nematodes of the order Tylenchida. Nematology 2:805-822.

Digiani, M. C. 1999. First record of the genus Syncuaria (Nematoda: Acuariidae) in Argentina, with description of a new species. Folia Parasitologica 46:139-144.

Dolinski, C. M., R. M. Souza, and S. P. Huang. 1996. Paratylenchus emmoti n. sp. (Nemata: Tylenchulidae) found in the 'cerrado' of central Brazil. Fitopatologia Brasiliera 21:414-417.

Dorris, M., P. De Ley, and M. L. Blaxter. 1999. Molecular analysis of nematode diversity and the evolution of parasitism. Parasitology Today 15:188-193. 
Dorris, M., M. E. Viney, and M. L. Blaxter. 2002. Molecular phylogenetic analysis of the genus Strongyloides and related nematodes. International Journal of Parasitology 32:1507-1517.

Doucet, M. E. 1981. Description de Dolichodorus longicaudatus n. sp. and Neodolichodorus leiocephalus $\mathrm{n}$. sp. (Nematoda: Tylenchida). Revue de Nématologie 4: 191-197.

Doucet, M. E., and S. Filisetti. 2000. Contribution to the knowledge of Belonolaimus brevianulata (Doucet, 1983) Fortuner and Luc, 1987 (Nematoda: Tylenchida). Journal of Nematode Morphology and Systematics 3: $39-47$.

Dróżdz, J., A. W. Demiaszkiewicz, and J. Lachowicz. 1998. Ashworthius sidemi (Nematoda, Trichostrongylidae) a new parasite of the European bison, Bison bonasus (L.) and the question of independence of $A$. gagarini. Acta Parasitologica 43:75-80.

Durette-Desset, M. C., J. P. Hugot, P. Darlu, and A. G. Chabaud. 1999. A cladistic analysis of the Trichostrongyloidea (Nematoda). International Journal of Parasitology 29:1065-1086.

Elekçioğlu, I. H. 2000. Diagnostic characteristics of Plesiorotylenchus striaticeps Vovlas, Castillo et Lamberti, 1993 (Nematoda: Tylenchida) from east Mediterranean region and central Anatolia. Nematologia Meditteranea 28:207-212.

Ebsary, B. A. 1991. Catalog of the Order Tylenchida (Nematoda). Research Branch, Agriculture Canada, Ottawa, Ontario, Canada. 196 pp.

Esser, R. P. 1992. A diagnostic compendium to species included in Paratylenchinae Thorne, 1949 and Tylenchocriconematinae Raski and Siddiqi, 1975 (Nematoda: Criconematoidea) Nematologica 38:146-163.

Esser, R. P., and N. Vovlas. 1990. A diagnostic compendium to the genus Hemicriconemoides (Tylenchida: Criconematidae). Soil and Crop Science Society of Florida Proceedings 49:211-219.

Eveland, L. K., T. Fujino, and B. Tried. 1990. Scanning electron microscopical observations of Pellioditis pellio (Nematoda: Secernnentia). Transactions of the American Microscopical Society 109:85-90.

Farooq, M., and N. Fatema. 1994. A new species of genus Scutylenchus Jairajpuri, 1971 (Nematoda: Merliniinae). Proceedings of the Pakistan Congress of Zoology 14: 147-150.

Fürst von Lieven, A., V. Bärmann, and W. Sudhaus. 2005. How can nematodes mate without spicules? Function of the male gonoduct glands in the roundworm Myolaimus. Zoology (Jena). 108:211-216.

Gerber, K., and R. M. Giblin-Davis. 1990. Teratorhabditis palmarum n. sp. (Nemata: Rhabditidae): an associate of Rhynchophorus palmarum and R. cruentatus. Journal of Nematology 22:337-347.

Gibbons, L. M. 1979. Revision of the genus Haemonchus Cobb, 1898 (Nematoda: Trichostrongylidae. Systematic Parasitology 1:3-24.

Gibbons, L. M. 1987. SEM Guide to the Morphology of Nematode Parasites of Vertebrates. Commonwealth Agricultural Bureaux, St. Albans, Buckinghamshire, U.K. 199 pp.

Giribet, G. 2003. Molecules, development and fossils in the study of metazoan evolution; Articulata versus Ecdysozoa revisited. Zoology 106:303-326.
Goodey, J. B., and T. Goodey. 1963. Soil and Freshwater Nematodes, 2nd ed. John Wiley and Sons, New York. 544 pp.

Gow, N. A. R. 2004. New angles in mycology: studies in directional growth and directional motility. Mycological Research 108:5-13.

Guerrero-Bosagna, C., P. Sabat, and L. Valladares. 2005. Environmental signaling and evolutionary change: can exposure of pregnant mammals to environmental estrogens lead to epigenetically induced evolutionary changes in embryos? Evolution and Development 7:341-350.

Haag, E. S., and J. R. True. 2001. Perspective: from mutants to mechanisms? Assessing the candidate gene paradigm in evolutionary biology. Evolution 55:10771084.

Hirschmann, H. 1971. Comparative Morphology and Anatomy. Pages 11-63 in B. M. Zuckerman, W. F. Mai, and R. A. Rohde, eds. Plant Parasitic Nematodes, Volume 1. Academic Press, New York. 345 pp.

Hoberg, E. P., A. Abrams, R. A. Carreno, and J. R. Lichtenfels. 2002. Ashworthius patriciapilittae n. sp. (Trichostrongyloidea: Haemonchinae) an abomasal nematode in Odocoileus virginianus from Costa Rica, and a new record for species of the genus in the Western Hemisphere. Journal of Parasitology 88:11871199.

Hoberg, E. P., and J. R. Lichtenfels. 1994. Phylogenetic systematic analysis of the Trichostrongylidae (Nematoda) with an initial assessment of coevolution and biogeography. Journal of Parasitology 80:976-996.

Hoberg, E. P., J. R. Lichtenfels, and P. A. Pilitt. 1993a. Affiliation of Hyostrongylus rubidus (Nematoda: Trichostrongylidae) with the Ostertagiinae, and evaluation of the synlophe and other structural characters. Journal of the Helminthological Society of Washington 60:219-233

Hoberg, E. P., J. R. Lichtenfels, and P. A. Pilitt. 1993b. Comparative morphology of Ostertagia mossi and Ostertagia dikmansi (Trichostrongylidae) from Odocoileus virginianus and comments on other Ostertagia spp. from the Cervidae. Systematic Parasitology 24: 111-127.

Hoberg, E. P., J. R. Lichtenfels, and P. A. Pilitt. 1993c. Synlophe of Cooperia neitzi (Trichostrongylidae: Cooperiinae) with comments on vulval inflations and hypertrophy of cuticular ridges among the trichostrongylids. Journal of the Helminthological Society of Washington 60:153-161.

Holovachov, O., and S. Boström. 2006. Description of Deleyia gen. n. with a discussion of its phylogenetic relationships to the genera Daubaylia Chitwood \& Chitwood, 1934 and Myolaimus Cobb, 1920 (Nematoda: Rhabditida). Nematology 8:223-233.

Holterman, M., A. van der Wurff, S. van den Elsen, H. van Megen, T. Bongers, O. Holovachov, J. Bakker, and J. Helder. 2006. Phylum-wide analysis of SSU rDNA reveals deep phylogenetic relationships among nematodes and accelerated evolution toward crown clades. Molecular Biology and Evolution 23:1792-1800.

Hood, T. E., E. J. Calabrese, and B. M. Zuckerman. 2000. Detection of an estrogen receptor in two nematode species and inhibition of binding and 
development by environmental chemicals. Ecotoxicology and Environmental Safety 47:74-81.

Hope, W. D. 1974. Nematoda. Pages 391-469 in A. C. Giese and J. S. Pearse, eds. Reproduction of Marine Invertebrates. Academic Press, New York. 546 pp.

Hunt, D. J. 1993. Aphelenchida, Longidoridae and Trichodoridae: Their Systematics and Bionomics. CAB International, St. Albans, U.K. 352 pp.

Hunt, D. J. 2001. The African Carnoyidae (Nematoda: Rhigonematida). 1. Brumptaemilius brevispiculus sp. $\mathrm{n}$. from Ghana with observations on copulatory plugs and spermatophore development. Nematology 3:313-323.

Jairajpuri, M. S., and M. J. Azmi. 1977. Reproductive behavior of Acrobeloides sp. Nematologica 23:202212.

Jairajpuri, M. S., and D. J. Hunt. 1984. The taxonomy of Tylenchorhynchinae (Nematoda: Tylenchida) with longitudinal lines and ridges. Systematic Parasitology 6:261-268.

Justine, J.-L. 1992. Une nouvelle espèce de nématode Capillariinae parasite de sorcidés (Mammalia, Insectivora) au Népal. Annales de Parasitologie Humaine et Comparée 67:9-18.

Kalia, D. C., and N. K. Gupta. 1984. On two new species of Skrjabinocapillaria Skarbilovitsch, 1946, from Micro-Chiroptera, with a key to species of the genus. Rivista Parassitologia 1:125-132.

Khera, S. 1969. Nematodes from the banks of still and running waters. VI. Rhabditida from sewer. Journal of Helminthology 43:347-363.

Kiontke, K. 1997. Description of Rhabditis (Caenorhabditis) drosophilae n. sp. and R. (C.) sonorae n. sp. (Nematoda: Rhabditida) from saguaro cactus rot in Arizona. Fundamental and applied Nematology 20: 305-315.

Kiontke, K., A. Barrière, I. Kolotuve, B. Podbilewicz, R. Sommer, D. H. A. Fitch, and M. A. Félix. 2007. Trends, stasis, and drift in the evolution of nematode vulva development. Current Biology 17:1925-1937.

Knight, C. G., M. N. Patel, R. B. R. Azevedo, and A. M. Leroi. 2002. A novel mode of ecdysozoan growth in Caenorhabditis elegans. Evolution and Development 4:16-27.

Kolotuev, I., and B. Podbilewicz. 2004. Pristionchus pacificus vulva formation: polarized division, cell migration, cell fusion, and evolution of invagination. Developmental Biology 266:322-333.

Lanfredi, R. M., W. De Souza, and D. C. Gomes. 1995. Comparative study of four species of Trichuris Roederer, 1761 (Nematoda, Trichurinae) by scanning electron microscopy. Memórias do Instituto Oswaldo Cruz, Rio de Janeiro 90:489-496.

Lee, D. L. 2002. Cuticle, moulting and exsheathment. Pages 171-209 in D. Lee, ed. The Biology of Nematodes. Taylor and Francis, London, U.K. 648 pp.

Lichtenfels, J. R., P. A. Pilitt, L. M. Gibbons, and J. D. F. Boomker. 2001. Haemonchus horaki n. sp. (nematode: Trichostrongyloidea) from grey rhebuck Pelea capreolus in South Africa. Journal of Parasitology 87:10951103.

Lichtenfels, J. R., P. A. Pilitt, and E. P. Hoberg. 1994. New morphological characters for identifying individual specimens of Haemonchus spp. (Nematoda: Trichostrongyloidea) and a key to species in ruminants of North America. Journal of Parasitology 80: 107-119.

Lorenzen, S. 1994. The phylogenetic systematics of freeliving nematodes. The Ray Society, London, U.K. 383 pp.

Maddison, W. P., and D. R. Maddison. 1992. MacClade: analysis of phylogeny and character evolution, version 3.05. Sinauer Associates, Sunderland, Massachusetts.

Maggenti, A. 1981. General Nematology. Springer Verlag, New York. 372 pp.

Malakhov, V. V. 1994. Nematodes. D. Hope, ed. Structure, Development, Classification and Phylogeny. Smithsonian Institution Press, Washington, D.C. 286 pp.

Mekete, R., R. A. Sikora, S. Kiewnick, and J. Hallman. 2008. Description of plant parasitic nematodes associated with coffee in Ethiopia. Nematologia Mediterranea 36:69-77.

Meldal, B. H., N. J Debenham,. P. De Ley, I. T. De Ley, J. R. Vanfleteren, A. R. Vierstraete, W. Bert, G. Borgonie, T. Moens, P. A. Tyler, M. C. Austen, M. L. Blaxter, A. D. Rogers, and P. D. Lambshead. 2007. A molecular phylogeny of the Nematoda with specific emphasis on the relationships of marine taxa. Molecular Phylogenetics and Evolution 42:622-636.

Michel, J. F., M. B. Lancaster, and C. Hong. 1972. The development and symmetry of the vulval flap of Ostertagia ostertagi. Journal of Parasitology 2:297304.

Michel, J. F., and I. J. Sinclair. 1969. The effect of cortisone on the worm burdens of calves infected daily with Ostertagia ostertagi. Parasitology 59:691-708.

Mounport, D., S. Bostrom, and C. Villenave. 2002. Description of Cervidellus baujardi n. sp. (Nematoda: Cephalobidae) from Senegal. Journal of Nematode Morphology and Systematics 4:111-117.

Nickle, W. R. 1970. A taxonomic review of the genera of the Aphelenchoidea (Fuchs, 1937) Thorne, 1949 (Nematoda: Tylenchida). Journal of Nematology 2:375-392.

Nickle, W. R. 1972. A contribution to our knowledge of the Mermithidae (Nematoda). Journal of Nematology 4: 113-146.

Nickle, W. R., A. M. Golden, Y. Mamiya, and W. P. Wergin. 1981. On the taxonomy and morphology of the pine wood nematode, Bursaphelenchus xylophilus (Steiner and Buhrer, 1934) Nickle 1970. Journal of Nematology 13:385-392.

Platt, H. M., and R. M. Warwick. 1983. Free living marine nematodes. Part 1: British enoplids. Pictorial key to world genera and notes for the identification of British species. Synopses of the British Fauna, No. 28. D. M. Kermack and R. S. K. Barnes, eds. Cambridge University Press, Cambridge, U.K. 307 pp.

Platt, H. M., and R. M. Warwick. 1988. Free living marine nematodes. Part II: British chromadorids. Synopses of the British Fauna, No. 38. D. M. Kermack and R. S. K. Barnes, eds. E. J. Brill/Dr. W. Backhuys, New York. 502 pp.

Poinar, G. O. 1975a. Description and biology of a new insect parasitic rhabditoid, Heterorhabditis bacteriophora n. gen., n. sp., (Rhabditida: Heterorhabditidae n. fam.). Nematologica 21:463-470.

Poinar, G. O. 1975b. Entomogenous Nematodes, A Manual and Host List of Insect-Nematode Associations. E. J. Brill, Leiden, The Netherlands. 317 pp. 
Poinar, G. O., T. A. Jackson, N. A. Bell, and M. B. Wahid. 2002. Elaeolenchus parthenonema n. g., n. sp. (Nematoda: Sphaerularioidea: Anandranematidae n. fam.) parasitic in the palm-pollinating weevil Elaeidobius kamerunicus Faust, with a phylogenetic synopsis of the Sphaerularioidea Lubbock, 1861. Systematic Parasitology 51:219-225.

Porter, D. 1986. Mycoses of marine organisms: an overview of pathogenic fungi. Pages 141-153 in S. T. Moss, ed. Biology of Marine Fungi. Cambridge University Press, New York. 382 pp.

Poulin, R. 1998. Evolutionary Ecology of Parasites. Chapman and Hall, New York. 212 pp.

Raski, D. J. 1975a. Revision of the genus Paratylenchus Micoletzky, 1922 and descriptions of new species. Part I of 3 parts. Journal of Nematology 7:15-34.

Raski, D. J. 1975b. Revision of the genus Paratylenchus Micoletzky, 1922, and descriptions of new species. Part II of 3 parts. Journal of Nematology 7:274-295.

Raski, D. J., P. K. Koshy, and V. K Sosamma. 1982. A revision of the subfamily Ecphyadophorinae Skarbilovich, 1959 (Tylenchida: Nematoda). Revue de Nématologie 5:119-138.

Sanwal, K. C. 1959. Cuticonema vivipara n. g. n. sp. a new saprophagous nematode of the subfamily Panagrolaiminae Thorne, 1937, from Canada, with a note on the genus Brevibucca Goodey, 1935. Canadian Journal of Zoology 37:223-229.

Sarr, E., A. Coomans, and M. Luc. 1987. Development and life cycle of Neodolichodorus rostrulatus (Siddiqi, 1976) with observations on the copulatory plug (Nematoda: Tylenchida). Revue de Nématologie 10: 87-92.

Sauer, M. R. 1965. Morulaimus, a new genus of the Belonolaiminae. Nematologica 11:609-618.

Schneider, A. 1866. Monographie der Nematoden. G. Reimer, Berlin, Germany. 357 pp.

Shahina, F., D. J. Hunt, and M. R. Siddiqi. 1996. Three new species of Aulolaimus de Man (Chromadorida: Aulolaimidae). Afro-Asian Journal of Nematology 6: 78-84.

Shahina, F., and M. A. Maqbool. 1992. Description of Deladenus pakistanensis n. sp., (Nematoda: Tylenchida) from Pakistan. Pakistan Journal of Nematology 10: $1-6$.

Sharma-Kishore, R., J. G. White, E. Southgate, and B. Podbilewicz. 1999. Formation of the vulva in Caenorhabditis elegans: a paradigm for organogenesis. Development 126:691-699.

Sher, S. A. 1963. Revision of the Hoplolaiminae (Nematoda) II. Hoplolaimus Daday, 1905 and Aorolaimus n. gen. Nematologica 9:267-295.

Siddiqi, M. R. 1980. Six new species of Coslenchus Siddiqi, 1978 (Nematoda: Tylenchidae). Nematologica 26:432-447.

Siddiqi, M. R. 2000. Tylenchida, Parasites of Plants and Insects, 2nd ed. Commonwealth Agricultural Bureaux Publishing, New York. 833 pp.

Siddiqi, M. R., and J. M. Lenne. 1984. Pterotylenchus cecidogenus $\mathrm{n}$. gen., n. sp., a new stem-gall nematode parasitizing Desmodium ovalifolium in Colombia. Journal of Nematology 16:62-65.

Skrjabin, K. I. 1949. Key to Parasitic Nematodes. Volume 1. Spirurata and Filariata. Academy of Sciences of the
U.S.S.R., St. Petersburg. Translated from Russian for the U.S. National Science Foundation and Department of Agriculture by the Israel Program for Scientific Translations. 1968. Office of Technical Services, U.S. Department of Commerce, Washington, D.C. $497 \mathrm{pp}$.

Skrjabin, K. I. 1951. Key to Parasitic Nematodes. Volume 2. Oxyurata and Ascaridata. Academy of Sciences of the U.S.S.R., St. Petersburg. Translated from Russian for the U.S. National Science Foundation and Department of Agriculture by the Amerind Publishing Co., New Delhi, India. 1982. Office of Technical Services, U.S. Department of Commerce, Washington, D.C. 703 pp.

Skrjabin, K. I. 1952. Key to parasitic nematodes, Volume 3. Strongylata. Academy of Sciences of the U.S.S.R., St. Petersburg. Translated from Russian for the U.S. National Science Foundation and Department of Agriculture by the Israel Program for Scientific Translations. 1961. Office of Technical Services, U.S. Department of Commerce, Washington, D.C. 890 pp.

Skrjabin, K. I. 1954. Key to Parasitic Nematodes. Volume 4. Camallanata, Rhabditata, Tylenchata, Trichocephalata, Dioctophymata, and Distribution of parasitic nematodes in different hosts. Academy of Sciences of the U.S.S.R., St. Petersburg. Translated from Russian for the U.S. National Science Foundation and Department of Agriculture by the Amerind Publishing Co., New Delhi, India. 1984. Office of Technical Services, U.S. Department of Commerce, Washington, D.C. $1097 \mathrm{pp}$

Smythe, A. B., M. J. Sanderson, and S. A. Nadler. 2006. Nematode small subunit phylogeny correlates with alignment parameters. Systematic Biology 55:972-992.

Southey, J. F. 1986. Laboratory Methods for Work with Plant and Soil Nematodes. Her Majesty's Stationery Office, London, U.K. 202 pp.

Speare, R. 1989. Identification of species of Strongyloides. Pages 11-82 in D. I. Grove, ed. Strongyloidiasis: An Important Roundworm Infection of Man. Taylor and Francis, London, U.K. 336 pp.

Steiner, G. 1929. On the gross morphology of Acrobeles (Acrobeles) crossotus n. sp. (Rhabditidae, Nematodes) found in diseased bulbs of Iris tingitana Boiss. and Reut. with remarks on its ecology and life cycle. Zeitschrift für Morphologie und Ökologie der Tiere Bd. 15:36-558.

Stock, S. P., J. F. Campbell, and S. A. Nadler. 2001 Phylogeny of Steinernema Travassos, 1927 (Cephalobina: Steinernematidae) inferred from ribosomal DNA sequences and morphological characters. Journal of Parasitology 87:877-889.

Sudhaus, W., and D. Fitch. 2001. Comparative studies on the phylogeny and systematics of the Rhabditidae (Nematoda). Journal of Nematology 33:1-70.

Sudhaus, W., and D. J. Hooper. 1994. Rhabditis (Oscheius) guentheri sp. n. an unusual species with reduced posterior ovary, with observations on the Dolichura and Insectivora groups (Nematoda: Rhabditidae). Nematologica 40:508-533.

Sudhaus, W., and K. Kiontke. 1996. Phylogeny of Rhabditis subgenus Caenorhabditis (Rhabditidae, 
Nematoda). Journal of Zoological, Systematic and Evolutionary Research 34:217-233.

Sudhaus, W., and R. Kúhne. 1989. Nematodes associated with Psychodidae: description of Rhabditis berolina sp. $\mathrm{n}$. and redescription of $R$. dubia Bovien, 1937 (Nematoda: Rhabditidae), with biological and ecological notes, and a phylogenetic discussion. Nematologica 35:305-320.

Thorne, G., and R. B. Malek. 1968. Nematodes of the Northern Great Plains, Part I, Tylenchida (Nemata: Secernentea). Technical Bulletin 31, Agricultural Experiment Station, South Dakota State University, Brookings, South Dakota. 111 pp.

Verschelde, D., and M. Vincx. 1994. Epsilonematidae (Nematoda: Desmodoroidea) from the east African coast, with a discussion on the external morphology of cuticular appendages. Nematologica 40:78105 .

Viney, M., R. W. Ashford, and G. Barnish. 1991. A taxonomic study of Strongyloides Grassi, 1879 (Nematoda) with special reference for Strongyloides fulleborni von Linstow, 1905 in man in Papua New Guinea and the description of a new subspecies. Systematic Parasitology 18:95-109.

Vincx, M. 1983. Redescription and ontogeny study of Desmodora schulzi Gerlach, 1950. Biologische Jaarboek, Dodonea 51:171-179.

Wagner, G., and K.-A. Seitz. 1983. Funktionsmorphologische Untersuchungen an Vagina, Vulva, Vulvapfropf und vulva-assoziierter Hypodermis bei Pelodera strongyloides (Nematoda, Rhabditidae). Nematologica 29: 190-202.

Warwick, R. M., H. M. Platt, and P. J. Somerfield. 1998. Free living marine nematodes. Part III: British monhysterids. Synopses of the British Fauna, No. 53 in D. M. Kermack and R. S. K. Barnes, eds. Field Studies Council, Shrewsbury, Shropshire, U.K. 296 pp.

Wergin, W. P., R. M. Sayre, and E. F. Erbe. 1993. Use of low temperature scanning electron microscopy to observe frozen hydrated specimens of nematodes. Journal of Nematology 25:214-226.

White, J. 1988. The Anatomy. Pages 81-122 in W. B. Wood, ed. The nematode $C$. elegans. Cold Spring Harbor Laboratory Press, New York. 667 pp.

Whitlock, J. H. and L. F. Le Jambre. 1981. On the taxonomic analysis of the genus Haemonchus Cobb, 1898. Systematic Parasitology 3:7-12.

Wilkes, C. P., F. J. Thompson, M. P. Gardner, S. Paterson, and M. E. Viney. 2004. The effect of the host immune response on the parasitic nematode Strongyloides ratti. Parasitology 128:661-669.

Wright, K. A. 1975. Cuticular inflations in whipworms, Trichuris spp. International Journal for Parasitology 5: 461-463.

Yin, K., Y. Fang, and A. C. Tarjan. 1988. A key to species in the genus Bursaphelenchus with a description of Bursaphelechus hunanensis sp. n. (Nematoda: Aphelenchoididae) found in pine wood in Hunan Province, China. Proceedings of the Helminthological Society of Washington. 55:1-11.

Yoon, H.-S., and D. A. Baum. 2004. Transgenic study of parallelism in plant morphological evolution. Proceed- ings of the National Academy of Sciences U.S.A. 101: 6524-6529.

Zarina, B., and M. A. Maqbool. 1998. Descriptions and observations on two new and two known species of the genus Pratylenchus Filipjev, 1936 (Nematoda: Pratylenchidae) from Pakistan. Pakistan Journal of Nematology 16:13-24.

Zhang, L., D. R. Brooks, and D. Causey. 2003. A new species of Syncuaria Gilbert, 1927 (Nematoda: Acuarioidea: Acuariidae) in the wood stork, Mycteria americana L. (Aves: Ciconiiformes: Ciconiidae) from the area de Conservacion Guanacaste, Costa Rica. Journal of Parasitology 89:1034-1038.

\section{APPENDIX 1}

Supplemental listing of vulval appendages represented on Figs. 20 and 21; vulval flap (f), vulval membrane (m), epiptygma (e)

\section{Adenophorea}

Mermithida, m: Tunicamermis melolonthae Schuurmans Stekhoven, Mason and Couturier, 1955 "lèvre en forme d'éventail" f: Amphimermis, Diximermis, Hydromermis, Lanceimermis, Limnomermis

Trichocephalida, m: "lateral alate membranes" Capillaria bursata Freitas and Almeida, 1934 (after Skrjavin, 1984 after Gagarin, 1952)

Enoplida, e: Deontostoma californicum (Hope, 1974)

Desmodorida, f-e: Epsilonema espeeli Verschelde and Vincx, 1994 -moderately post vulva, 1 testis

Chromadorida, m: Aulolaimus filicaudatus (Timm, 1957) Jairajpuri and Hooper, 1968, in Shahina, Hunt and Siddiqi, 1996 (V = 37), not parasitic or obviously commensal

Monhysterida, f-e: Diplolaimella dievengatensis Jacobs, Van de Velde, Geraert and Vranken, 1990, "flap," (the order has some commensal species)

\section{Secernentea}

Oxyurida, f: Avilandros avis Maplestone, 1940

Rhigonematida, e: Rhigonema Cobb, 1898

Tylenchida, m: Deladenus pakistanensis Shahina and Maqbool, 1992, Coslenchus (Siddiqi, 1980), Cephalenchus (Siddiqi, 2000), and Pterotylenchus (prominent) (Siddiqi and Lenne, 1984); Neodolichorhynchus (Mulkorhynchus) phaseoli (Sethi and Swarup, 1968) Talavera and Tobar, 1997, Scutylenchus fici Farooq and Fatema, 1994 (Farooq and Fatema, 1994); Belonolaimus synonym: Ibipora jara Monteiro and Lordello, 1977, I. anama Monteiro and Lordello, 1977, I. lineatus (Román, 1964) Monteiro and Lordello 
Helicotylenchus limatus Siddiqi, 1995 (Paratylenchus spp., Hemicriconemoides spp., Pratylenchus roseus Zarina and Maqbool, 1998

f: Ecphyadophora espeeli; Elaeolenchus parthenonema Poinar, Jackson, Bell and Wahid, 2002

e: small - Histotylenchus histoides Siddiqi, 1971, Morulaimus arenicolus Sauer, 1966; Neodolichodorus obtusus (Allen, 1957) Andrassy, 1976; Tylenchorhynchus tuberosus Zarina and Maqbool, 1994; Merlinius spp., Scutylenchus fici; large Hoplolaimus seinhorsti Sher, 1963; some Peltamigratus spp. and Scutellonema spp., Plesiorotylenchus striaticeps Elekçioğlu, 2000

Aphelenchida, Aphelenchoidoidea, f-e: Aphelenchoides vigor Thorne \& Malek, 1968, Bursaphelenchus (one third of species), Laimaphelenchus (many), Rhadinaphelenchus cocophilus (Cobb,
1919) J. B. Goodey, 1960 (Hunt, 1993), Seinura (many) (Massey, 1974)

Steinernematida, e: Steinernema (some)

Rhabditida-Panagrolaimidae, m: Cuticonema vivipara Sanwal, 1959

Rhabditida-Rhabditoidea, m: small in Oscheius guentheri, Caenorhabditis elegans, larger in Caenorhabditis sonore, very large in C. drosophilae and Choriorhabditis dubia Bovien, 1937 and perhaps Operculorhabditis longispiculosa Khera, 1969

Strongylida. f: Ostertagia, Haemonchus, Paracooperia spp.; Inflation (irregular): Longiostrongylus, Mazamastrongylus, Camelostrongylus m: Cooperia spp. (3 in Hoberg et al., 1993), Allintoshius nycticeius Chitwood, 1937

Paratylenchus 
APPENDIX 2

Membrane size and vulval position after Esser (1992), p. 12

\begin{tabular}{|c|c|}
\hline Paratylenchus (Paratylenchus) & $\mathrm{V} \%$ \\
\hline \multicolumn{2}{|l|}{ Anterior, no membrane } \\
\hline P. (P). aciculus Brown 1959 & $68-74$ \\
\hline P. $(P)$. acti Eroshenko, 1978 & $69-73$ \\
\hline P. $(P)$. aculentus Brown 1959 & $71-73$ \\
\hline P. (P). costatus (Raski, 1976) Siddiqi, 1986 & $68-72$ \\
\hline P. (P). laocaiensis Nguyen et al., 2004 & $65-67$ \\
\hline P. $(P)$. minisculus Tarjan, 1960 & $69-81$ \\
\hline P. $(P)$. macrodorus Brzeski, 1963 & $74-81$ \\
\hline P. $(P)$. pandatus Raski, 1976 & $70-78$ \\
\hline P. $(P)$. steineri Golden, 1961 & $75-78$ \\
\hline \multicolumn{2}{|l|}{ Intermediate, small membranes } \\
\hline \multicolumn{2}{|c|}{ P. (P). corbetti (Ganguly and Khan, 1990) Brzeski, $199875-81 \mathrm{~m}$ not prominent } \\
\hline \multicolumn{2}{|c|}{ P. $(P)$. discocephalus Siddiqi, Khan and Ganguly, $199073-80 \mathrm{~m}$ indistinct } \\
\hline \multicolumn{2}{|c|}{ Posterior, large membranes } \\
\hline$P .(P)$. arculatus Luc and de Guiran, 1962 & $78-84$ \\
\hline$P .(P)$. dianthus Jenkins and Taylor, 1956 & $80-88 \mathrm{~m}$ large, 4-6 annules \\
\hline P. $(P)$. elachistus Steiner, 1949 & $82-87$ \\
\hline P. (P). flectospiculus Huang and Raski, 1987 & $81-86$ \\
\hline P. $(P)$. holdemani Raski, 1975 & $84-86$ \\
\hline P. $(P)$. microdorus Andrássy, 1959 & $79-86$ \\
\hline P. $(P)$. perlatus Raski, 1975 & $79-86$ \\
\hline P. (P.) projectus Jenkins, 1956 & $83-87$ \\
\hline \multicolumn{2}{|l|}{ Paratylenchus (Gracilacus) } \\
\hline \multicolumn{2}{|l|}{ Anterior } \\
\hline \multicolumn{2}{|c|}{ P. $(G)$. capitatus (Adams and Eichenmuller, 1962) Siddiqi and Goodey, 1964} \\
\hline$P .(G)$. costata Raski, 1986 & $67-72$ \\
\hline P. $(G)$. elegans Raski, 1962 & $70-74$ \\
\hline P. (G). idalima Raski, 1962 & $71-76$ \\
\hline P. $(G)$. latescens Huang and Raski, 1986 & $68-73$ \\
\hline P. (G). marylandica (Jenkins, 1960) Raski, 1962 & $71-79$ \\
\hline P. $(G)$. oostenbrinki Misra and Edwards, 1971 & $70-73$ \\
\hline P. $(G)$. raskii Phukan and Sanwal, 1979 & $70-74$ \\
\hline \multicolumn{2}{|l|}{ Posterior } \\
\hline P. $(G)$. epacris Raski, 1962 & $82-87$ \\
\hline P. (G). mirus Raski, 1962 & $80-86$ \\
\hline P. $(G)$. robusta $(\mathrm{Wu}, 1974)$ Raski, 1976 & $81-85$ \\
\hline
\end{tabular}

